NATIONAL LABORATORY

MANAGED BY UT-BATTELLE

FOR THE DEPARTMENT OF ENERGY

\title{
DOE/EM Criticality Safety Needs Assessment
}

\author{
January 2011
}

Prepared by

R. M. Westfall

C. M. Hopper, CS Engineering

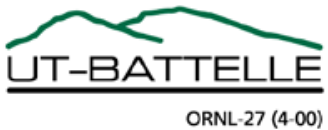




\title{
DOCUMENT AVAILABILITY
}

Reports produced after January 1, 1996, are generally available free via the U.S. Department of Energy (DOE) Information Bridge.

Web site http://www.osti.gov/bridge

Reports produced before January 1, 1996, may be purchased by members of the public from the following source.

\author{
National Technical Information Service \\ 5285 Port Royal Road \\ Springfield, VA 22161 \\ Telephone 703-605-6000 (1-800-553-6847) \\ TDD 703-487-4639 \\ Fax 703-605-6900 \\ E-mail info@ntis.gov \\ Web site http://www.ntis.gov/support/ordernowabout.htm
}

Reports are available to DOE employees, DOE contractors, Energy Technology Data Exchange (ETDE) representatives, and International Nuclear Information System (INIS) representatives from the following source.

Office of Scientific and Technical Information

P.O. Box 62

Oak Ridge, TN 37831

Telephone 865-576-8401

Fax 865-576-5728

E-mail reports@osti.gov

Web site http://www.osti.gov/contact.html

This report was prepared as an account of work sponsored by an agency of the United States Government. Neither the United States Government nor any agency thereof, nor any of their employees, makes any warranty, express or implied, or assumes any legal liability or responsibility for the accuracy, completeness, or usefulness of any information, apparatus, product, or process disclosed, or represents that its use would not infringe privately owned rights. Reference herein to any specific commercial product, process, or service by trade name, trademark, manufacturer, or otherwise, does not necessarily constitute or imply its endorsement, recommendation, or favoring by the United States Government or any agency thereof. The views and opinions of authors expressed herein do not necessarily state or reflect those of the United States Government or any agency thereof. 
Nuclear Science and Technology Division

\title{
DOE/EM CRITICALITY SAFETY NEEDS ASSESSMENT
}

\author{
R. M. Westfall \\ C. M. Hopper, CS Engineering
}

Date Published: January 2011

Prepared by

OAK RIDGE NATIONAL LABORATORY

Oak Ridge, Tennessee 37831-6283

managed by

UT-BATTELLE, LLC

for the

U.S. DEPARTMENT OF ENERGY under contract DE-AC05-00OR22725 



\section{CONTENTS}

Page

ACRONYMS AND ABBREVIATED TERMS ....................................................................... vii

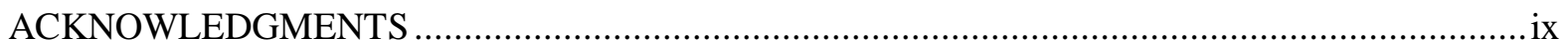

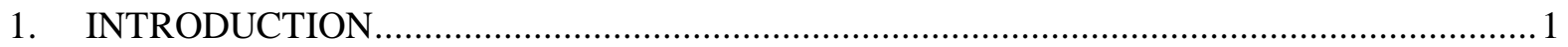

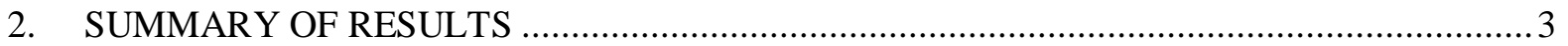

2.1 RESULTS OF NCS NEEDS ADDRESSED AT WORKSHOPS .................................... 3

2.1.1 Regulatory Inconsistencies and Implementation Problems ................................. 3

2.1.2 Inadequate Criticality Safety Evaluations......................................................... 3

2.1.3 Weak Fissile-Mass Characterization Programs in the Department ....................... 3

2.1.4 Complex Wide Repository for NCS Evaluations (NCSEs) ................................. 4

2.1.5 Lack of Standardized Criticality Safety Evaluations for Transportation

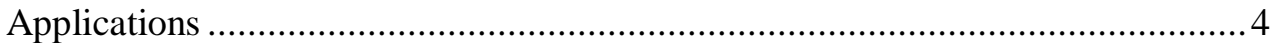

2.1.6 Criticality Detection and Alarm Systems for EM Applications ............................ 4

2.1.7 Experiments and Data Needs to Enhance EM Mission Work with Cost and

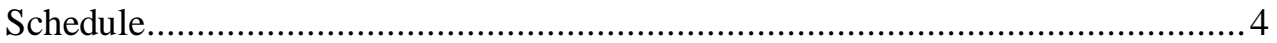

2.1.8 Ineffective Use of Nonconformance Data and Lessons Learned to Avoid Repeat Problems

2.1.9 The Problems that Recent DOE Contracting Practices have Engendered on the Practice of Criticality Safety ................................................................................. 4

2.1.10 The Problem of Contractor NCS Staffing and Staff Retention .............................. 4

2.2 RESULTS OF TECHNICAL SUPPORT FOR EM SITE APPLICATIONS ................... 5

2.2.1 Idaho National Laboratory (INL) ................................................................. 5

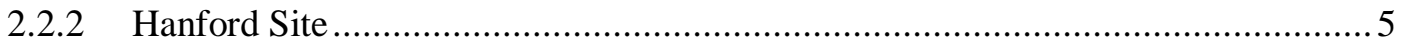

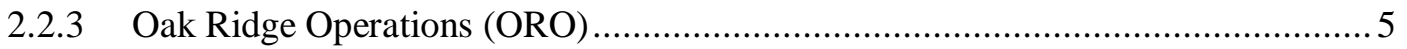

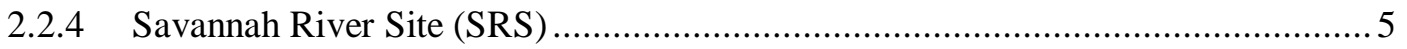

2.2.5 Training in Advanced Analytical Methods ...................................................... 6

2.2.6 NCS Assessments of EM Contractor Programs ................................................. 6

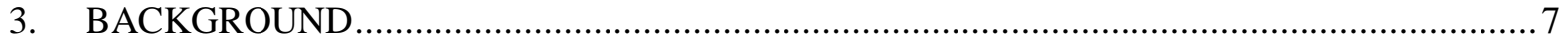

4. TOPIC NEEDS IDENTIFIED AT DOE/EM WORKSHOPS …............................................ 9

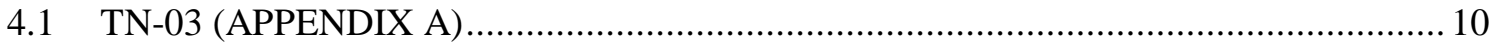

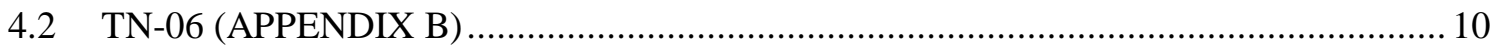

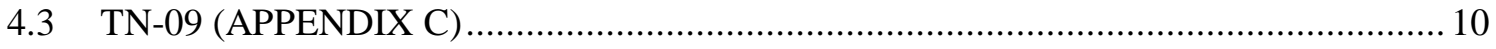

4.4 TOPIC NEEDS EXCLUDED FROM PROGRAM................................................... 10 


\section{CONTENTS (continued)}

Page

4.5 FUTURE WORK ON THE TOPIC NEEDS.............................................................. 11

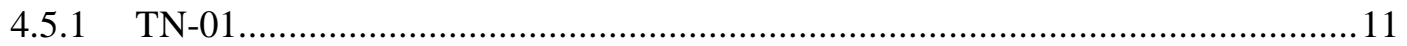

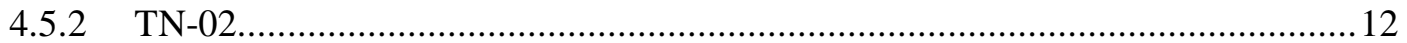

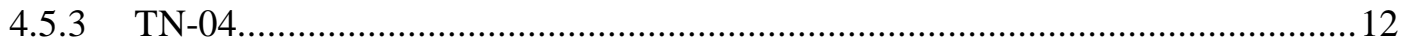

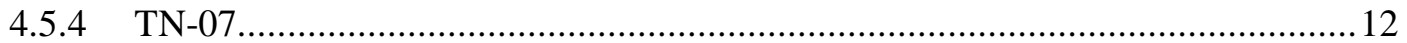

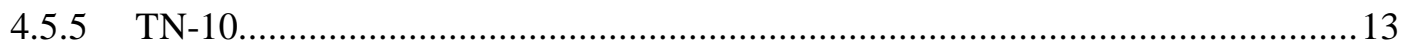

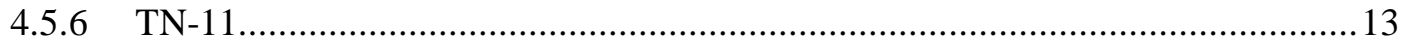

5. IDENTIFIED NEEDS ARISING FROM TECHNICAL SUPPORT, TRAINING, AND ASSESSMENT OF ON-SITE CONTRACTOR OPERATIONS .............................................15

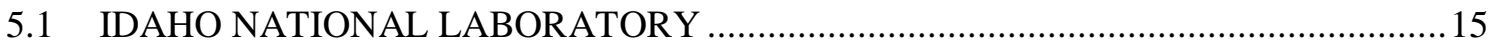

5.1.1 Analytical Technical Support and Training ................................................. 15

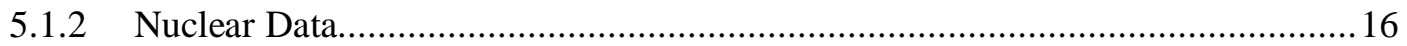

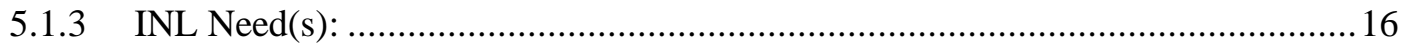

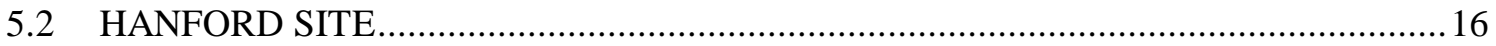

5.2.1 Analytical Technical Support and Training .................................................. 16

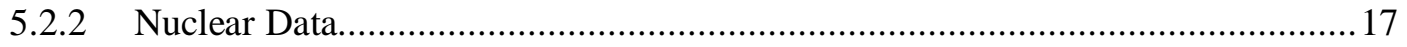

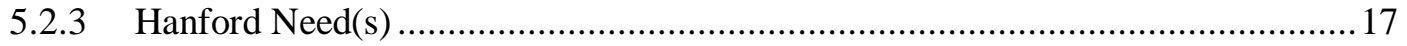

5.2.4 Hanford Operational Assessment ..................................................................... 18

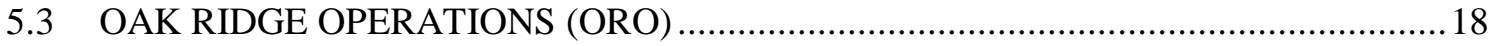

5.3.1 ORNL Radiochemical Development Facility (Isotek Operations) .......................18

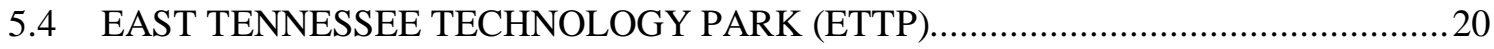

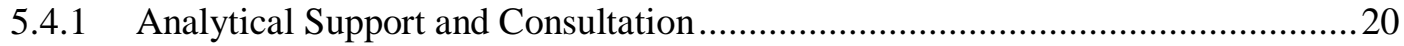

5.5 PORTSMOUTH GASEOUS DIFFUSION PLANT (PORTS) .....................................20

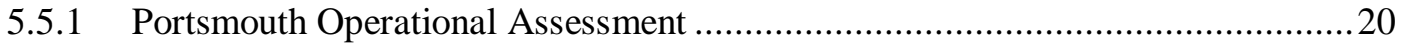

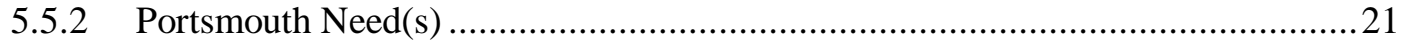

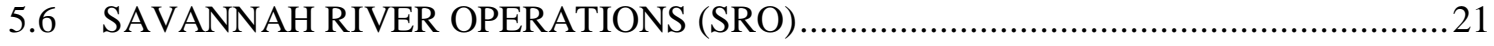

5.6.1 SRS Operational Review, Analytical Technical Support, and Training ...............21

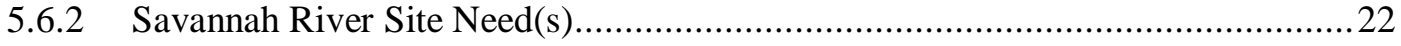

6. SUMMARY OF RESULTS OF THIS NEEDS ASSESSMENT …........................................23

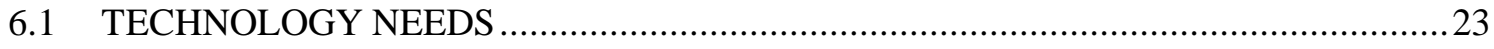

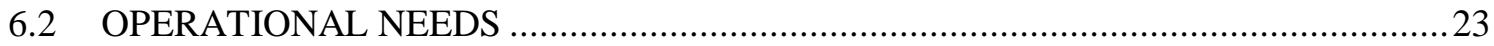




\section{CONTENTS (continued)}

Page

6.2.1 Regulatory Inconsistencies and Implementation Problems ................................ 23

6.2.2 Inadequate Criticality Safety Evaluations......................................................... 23

6.2.3 Weak Fissile-Mass Characterization Programs.................................................... 24

6.2.4 Complex-Wide Repository for NCS Evaluations.............................................. 24

6.2.5 Lack of Standardized Criticality Safety Evaluations for Transportation

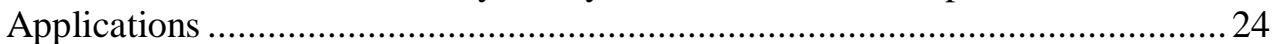

6.2.6 Criticality Detection and Alarm Systems .......................................................... 24

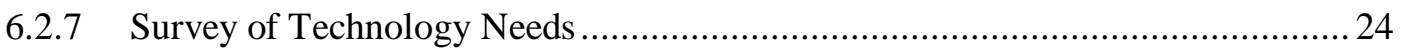

6.2.8 Ineffective Use of Nonconformance Data and Lessons Learned ......................... 24

6.2.9 Problems that Recent DOE Contracting Practices Have Engendered on Criticality Safety Practice ................................................................................. 24

6.2.10 Problem of Contractor NCS Staffing and Staff Retention ................................. 24

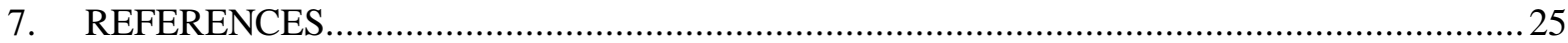

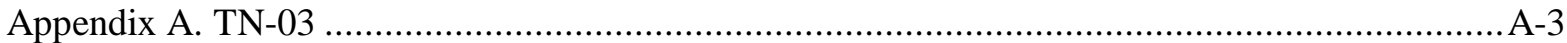

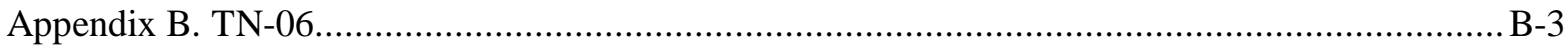

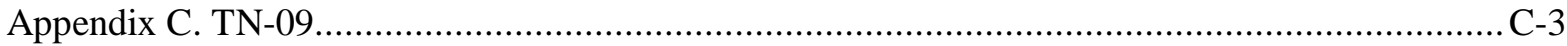

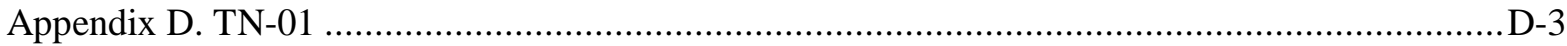

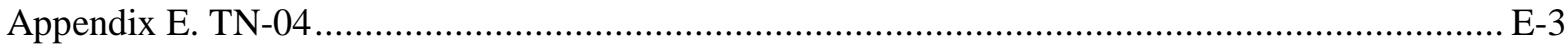

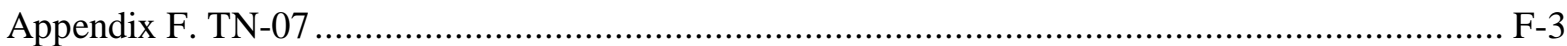

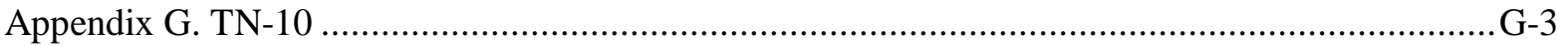





\section{ACRONYMS AND ABBREVIATED TERMS}

\begin{tabular}{|c|c|}
\hline $\mathrm{AL}$ & Albuquerque Operations (DOE) \\
\hline ANS & American Nuclear Society \\
\hline ANSI & American National Standards Institute \\
\hline CAAS & Criticality Accident Alarm System \\
\hline CEUSP & Consolidated Edison Uranium Solidification Program \\
\hline CSE & Criticality Safety Evaluation \\
\hline CSER & Criticality Safety Evaluation Report \\
\hline CSSG & Criticality Safety Support Group \\
\hline DOE & U.S. Department of Energy \\
\hline DWPF & Defense Waste Processing Facility \\
\hline EALF & energy of average neutron lethargy causing fission \\
\hline EFCOG & Energy Facility Contractors Group \\
\hline EM & Environmental Management (DOE) \\
\hline ETTP & East Tennessee Technology Park \\
\hline HAZOP & hazard and operability \\
\hline HEU & highly enriched uranium \\
\hline HQ & DOE Headquarters \\
\hline INL & Idaho National Laboratory \\
\hline ID & Idaho Operations (DOE) \\
\hline IFSF & Irradiated Fuel Storage Facility \\
\hline IHECSBE & International Handbook of Evaluated Criticality Safety Benchmark Experiments \\
\hline IEU & intermediate-enriched uranium \\
\hline LANL & Los Alamos National Laboratory \\
\hline LEU & low-enriched uranium \\
\hline LPP & LATA/Parallax Portsmouth \\
\hline MST & monosodium titanate \\
\hline NCS & Nuclear Criticality Safety \\
\hline NCSD & Nuclear Criticality Safety Division (ANS) \\
\hline NCSE & Nuclear Criticality Safety Evaluation \\
\hline NCSET & Nuclear Criticality Safety Engineer Training \\
\hline NCSP & Nuclear Criticality Safety Program (DOE) \\
\hline NDA & nondestructive assay \\
\hline NE & Office of Nuclear Energy (DOE) \\
\hline NNSA & National Nuclear Security Administration \\
\hline ORNL & Oak Ridge National Laboratory \\
\hline ORO & Oak Ridge Operations (DOE) \\
\hline PINS & Project Initiation Notification System \\
\hline PORTS & Portsmouth Gaseous Diffusion Plant \\
\hline RL & Richland Operations (DOE), manager of the Hanford Site \\
\hline RW & Office of Civilian Radioactive Waste Management (DOE) \\
\hline SC & Office of Science (DOE) \\
\hline SRO & Savannah River Operations \\
\hline SRS & Savannah River Site \\
\hline $\mathrm{TN}$ & Topic Need \\
\hline USL & upper safety limit or upper subcritical limit \\
\hline WTP & Waste Treatment Plant (Hanford) \\
\hline
\end{tabular}





\section{ACKNOWLEDGMENTS}

The authors gratefully acknowledge the leadership and direction of Robert E. Wilson, Department of Energy (DOE)/Environmental Management (EM) Nuclear Criticality Safety (NCS) Program Manager, and Chuan-Fu Wu, EM-21, Director of the Office of Safety Management. Their interest in, support of, and participation in this effort have been fundamental to its success.

The authors are equally grateful to the many NCS specialists_-DOE/EM federal and EM contractor personnel—who have participated in the workshops, surveys, and operational/technical activities that form the basis of this effort. The authors have attempted to recognize their contributions in the text. Additionally, the authors recognize the efforts of their colleagues at the Oak Ridge National Laboratory: Brad Rearden, Luiz Leal, Bryan Broadhead, Goran Arbanas, Charles Slater, Mark Williams, Davis Reed, Don Mueller, Pat Fox, Karla Elam, Daniel Hollenbach, Dorothea Wiarda, Klaus Guber, Royce Sayer, Nancy Larson, Herve Derrien, Michael Dunn, John Wagner, and Cecil Parks.

Finally, the preparation of this report for publication by Sandra Poarch and Marsha Savage is gratefully acknowledged by the authors. 



\section{INTRODUCTION}

The issue of nuclear criticality safety (NCS) in Department of Energy Environmental Management (DOE/EM) fissionable material operations presents challenges because of the large quantities of material present in the facilities and equipment that are committed to storage and/or material conditioning and dispositioning processes. Given the uncertainty associated with the material and conditions for many DOE/EM fissionable material operations, ensuring safety while maintaining operational efficiency requires the application of the most-effective criticality safety practices. In turn, more-efficient implementation of these practices can be achieved if the best NCS technologies are utilized.

In 2002, DOE/EM-1 commissioned a survey of criticality safety technical needs at the major EM sites. These needs were documented in the report Analysis of Nuclear Criticality Safety Technology Supporting the Environmental Management Program, issued May 2002 (ref. 1).

Subsequent to this study, EM safety management personnel made a commitment to applying the best and latest criticality safety technology, as described by the DOE Nuclear Criticality Safety Program

(NCSP). Over the past 7 years, this commitment has enabled the transfer of several new technologies to EM operations.

In 2008, it was decided to broaden the basis of the EM NCS needs assessment to include not only current needs for technologies but also NCS operational areas with potential for improvements in controls, analysis, and regulations. A series of NCS workshops has been conducted over the past years, and needs have been identified and addressed by EM staff and contractor personnel. These workshops were organized and conducted by the EM Criticality Safety Program Manager with administrative and technical support by staff at Oak Ridge National Laboratory (ORNL).

This report records the progress made in identifying the needs, determining the approaches for addressing these needs, and assimilating new NCS technologies into EM fissionable material operations. In addition, the report includes projections of future EM needs and associated recommendations. 



\section{SUMMARY OF RESULTS}

Specific and incisive NCS program and technical reviews performed by ORNL at selected DOE/EM sites and locations since 2002 have revealed very similar programmatic, regulatory, and technical needs among the sites. These issues were subsequently formally identified and affirmed by the five workshops held since February 2008. The results of the workshops and the direct technical support provided by ORNL staff are summarized.

\subsection{RESULTS OF NCS NEEDS ADDRESSED AT WORKSHOPS}

Initially, 10 Topic Needs (TNs) were identified at the 3-day workshop conducted at ORNL in February 2008. The EM sites were well represented by NCS site specialists, as well as EM site safety and operations managers. Subsequently, work groups addressing these TNs reported their results for discussion at four 1-day workshops organized by the EM NCS program manager, Robert E. Wilson, and conducted at 6-month intervals in 2008 and 2009. The activities of the work groups are described in the following sections. More information about the specific TNs is provided in Appendixes A-G.

\subsubsection{Regulatory Inconsistencies and Implementation Problems}

This work group has surveyed each DOE site and contractor for information on practical problems caused by DOE regulations that were implemented to ensure safe and efficient nuclear operations. Results of the survey were discussed at the follow-on meetings to confirm that the problems were widespread, and proposed solutions were then developed. The work group is coordinating with a DOE/Energy Facility Contractors Group (EFCOG) committee in proposing alternative regulatory language. The first projects are to address DOE-STD-1027 (ref. 2) and DOE-STD-3007 (ref. 3).

\subsubsection{Inadequate Criticality Safety Evaluations}

This work group reviewed the site problems and work stoppages caused by poor evaluations and determined that the path forward should be to further educate practicing criticality safety engineers. The first work product was a new white paper on developing Criticality Safety Evaluations (CSEs) to be issued by the Nuclear Criticality Safety Division (NCSD) of the American Nuclear Society (ANS). This paper was issued at the November 2009 ANS meeting. The second work product was a revision of the Nuclear Criticality Safety Engineer Training (NCSET) module on CSEs located on the DOE NCSP web site. A report on this EM-sponsored project was given at the November 2009 workshop. A revised module and operational example have been developed and provided to the NCSP for posting on the web. The third project is two workshops on the topic of hazard analysis, held for criticality safety practitioners at the June ANS meeting in San Diego and the November ANS meeting in Las Vegas.

\subsubsection{Weak Fissile-Mass Characterization Programs in the Department}

This work group determined that the DOE was developing a program to address part of the problem of characterizing fissile masses and decided a white paper on the issue was needed. The white paper was produced, approved by the workshop attendees, and provided to EM management and the DOE Non Destructive Analysis work group. 


\subsubsection{Complex Wide Repository for NCS Evaluations (NCSEs)}

This work group was subsumed by the DOE NCSP, which already has a documents repository. The program has worked out the ground rules for this venture and now has the objective of collecting the titles of NCSEs from each DOE site. A contact person at each site is to provide a list of NCSEs that may be of interest to practitioners in the NCS community.

\subsubsection{Lack of Standardized Criticality Safety Evaluations for Transportation Applications}

This work group surveyed the DOE sites and determined that the extent of the problems did not warrant significant effort. Thus, this project was closed.

\subsubsection{Criticality Detection and Alarm Systems for EM Applications}

This work group developed a white paper on the problems of maintaining the Criticality Accident Alarm Systems (CAASs) detailed in the regulations. Included are suggested ways for the department to approve appropriate exemptions. The white paper was provided to those DOE staff that had NCS oversight responsibilities.

\subsubsection{Experiments and Data Needs to Enhance EM Mission Work with Cost and Schedule}

This work group has continued the site surveys begun in 2002. With the assistance of DOE/EM-21 and DOE site/location and contractor NCS staffs, a substantial and comprehensive list of experiments and data needs was identified (see Appendix F). Without information related to experiments and materials information pertinent to EM mission work (e.g., decontamination, demolition, disposal/burial), NCS staffs must apply excessively restrictive assumptions within their evaluations, thereby negatively impacting the efficiency of operations (i.e., costs and schedules). Addressing this TN requires the identification of sponsors for the work. At the June 2009 workshop, ongoing discussions of new integral and differential data for the validation of titanium as a neutron absorber in the design qualification of the monosodium titanate (MST) Salt-Waste Disposition process was summarized. At the November 2009 workshop, interested NCSP technical personnel continued the discussion of potential new measurements.

\subsubsection{Ineffective Use of Nonconformance Data and Lessons Learned to Avoid Repeat Problems}

This work group could not determine appropriate actions to address the issue, but the work group did determine it was a significant DOE-wide problem. The topic remains open for possible future work.

\subsubsection{The Problems that Recent DOE Contracting Practices have Engendered on the Practice of Criticality Safety}

The work group determined that their only possible action was to describe the problem areas. A white paper was written, reviewed by the workshop participants, and then provided to EM management.

\subsubsection{The Problem of Contractor NCS Staffing and Staff Retention}

This work group determined that developing a white paper on the topic would be the extent of their action. With the assistance of DOE site/location and contractor NCS staffs, the trends and needs associated with the retiring workforce and nuclear industry growth were surveyed (see Appendix G). The group also acknowledged that hiring and compensation issues are beyond the scope of their control. A white paper was written, reviewed by the workshop attendees, and provided to the participants. 


\subsection{RESULTS OF TECHNICAL SUPPORT FOR EM SITE APPLICATIONS}

\subsubsection{Idaho National Laboratory (INL)}

The SCALE/TSUNAMI sensitivity analysis program (ref. 4) was used to analyze the Irradiated Fuel Storage Facility (IFSF), with discrete representation of each of the 13 reactor fuel types. There were 8 conclusions as to how methods and nuclear data fit this application when compared with 217 benchmark experiments. Improved nuclear data for ten nuclides have been developed for INL applications. These include the Idaho Cleanup Project and the Advanced Mixed-Waste Treatment Project. Better integral benchmark experimental data for ${ }^{233} \mathrm{U}$ systems in the epithermal neutron energy range would be useful in future NCS validations of equipment and operations for disposition of the ${ }^{233} \mathrm{U}$ fuel inventory at INL.

\subsubsection{Hanford Site}

The SCALE/TSUNAMI sensitivity analysis program was used to analyze transuranic waste drum models, as well as plutonium in conservative and representative Hanford waste tank models. In comparison with the results for 164 benchmark experiments, upper safety limits (USLs) were established for 6 models of these applications. Improved nuclear data for eight nuclides have been developed for six additional Hanford applications. Improved data for $\mathrm{Cu}, \mathrm{Ca}$, and $\mathrm{Ce}$ are scheduled for development. Improved data for soluble absorber applications in the Defense Waste Processing Facility (DWPF) would be useful in the qualification of NCS control strategies based upon admixed soluble neutron absorbers. These control strategies can facilitate significant increases in product throughput and therefore benefit overall process efficiency.

\subsubsection{Oak Ridge Operations (ORO)}

The SCALE/TSUNAMI sensitivity analysis program was used to analyze dispositioning operations to be performed by Isotek at ORNL (ref. 5). In comparison with the results for 672 benchmark experiments, USLs were established for four models of these applications. The SCALE/TSURFER uncertainty analysis program was used to address the overall uncertainties in the subcritical margins, which were primarily the results of data uncertainties. Better integral benchmark experimental data for ${ }^{233} \mathrm{U}$ systems in the epithermal neutron energy range would be useful in the validation of ${ }^{233} \mathrm{U}$ material-conditioning operations resulting in partially moderated systems.

ORNL staff consulted with East Tennessee Technology Park (ETTP) and ORO safety management and staff on the technical aspects of the nondestructive assay (NDA) approach in the evaluation of uranium product holdup and deposits. The areas addressed included inherent ${ }^{234} \mathrm{U}$ neutron source strength as a function of product history, transport of neutrons through the product/containment and their subsequent availability for NDA detection, and product quantity/geometry interpretation and estimates from NDA detection.

\subsubsection{Savannah River Site (SRS)}

Operations reviewed included those in which a plutonium waste stream was considered for control by a soluble gadolinium absorber in levels of neutron moderation varying from thermal (liquid media) to epithermal (glass media). One result of the study was the generation of new uncertainty data for use in the qualification of potential operations involving gadolinium. With the recent release of ENDF/B-VII, these data are now available to the NCS community.

A second result of the study involved the evaluation of neutron absorption by titanium as MST in the extraction of actinides in the salt-waste treatment process. For this application, improvement in the 
titanium cross-section uncertainty resulted in reduction of the uncertainty in the subcritical margin from $\sim 4 \% k_{\text {eff }}$ to less than $1 \%$ (ref. 6). Requests for improved integral benchmark experimental data and improved thermal-neutron cross-section data have been conveyed to the appropriate elements of the NCSP.

\subsubsection{Training in Advanced Analytical Methods}

ORNL staff expertise in the performance of sensitivity/uncertainty analyses was shared with EM NCS analysis specialists.

Idaho National Laboratory. ORNL staff provided general SCALE/TSUNAMI

Sensitivity/Uncertainty training for ten participants at Idaho Falls in August 2003.

Hanford Site. ORNL staff provided 15 Hanford staff members with a training tutorial in AugustSeptember 2004.

Savannah River Site. ORNL provided 15 SRS staff members with training tutorials. In August 2004, 15 participants attended Gadolinium/Plutonium Studies; in May 2008; 15 participants attended the, SCALE/TSUNAMI Refresher, and Titanium Uncertainty Studies).

\subsubsection{NCS Assessments of EM Contractor Programs}

ORNL staff expertise in the performance of NCS evaluations for enriched uranium and the higher actinides, as well as NCS operational experience, was included in EM NCS program assessments.

\subsubsection{Hanford Operational Review}

This assessment (ref. 7) was conducted on December 9-11, 2008. It resulted in five Recommendations and nine Opportunities for Improvement, as well as the identification of two Positive Practices.

\subsubsection{Portsmouth Operational Review}

This assessment was conducted in the summer of 2008. Results from this review included three Findings, two Recommendations, and four Opportunities for Improvement. 


\section{BACKGROUND}

This report provides ORNL's overall assessment of DOE/EM NCS needs. The objectives of the ORNL assessment were to identify NCS program drivers and technologies that could contribute directly to accomplishing the accelerated risk-based cleanup and closure mission of EM. To achieve these goals, ORNL has provided direct analytical support, technical training, and participation in site program reviews. With EM staff members providing direction, consultation, and participation, the assessment involved four types of ORNL support:

1. administrative assistance and logistical support for the conduct of five DOE/EM NCS Needs Workshops,

2. specialized analytical technical support for EM site applications,

3. training in advanced analytical methods for EM contractor specialists, and

4. participation in the review of on-site EM contractor NCS operations and programs.

Objectives of the five DOE/EM workshops were potential NCSE improvements for operational efficiencies, as identified by federal NCS specialists and contractor NCS staff members. The results from these workshops have affirmed and supplemented the assessments from the ORNL technical support and on-site reviews. Conduct of the workshops and the status of results, including action items, are described in Sect. 4 of this report.

The subsequent sections of this report are organized by the DOE/EM sites: Idaho National Laboratory (INL), Hanford Site (designated RL for DOE Richland Operations), Oak Ridge Office (ORO), and Savannah River Operations (SRO). Participants included both contractor and federal staff members.

The technical support was derived from ORNL's recently developed $k_{\text {eff }}$ sensitivity and uncertainty analytical technology (i.e., SCALE TSUNAMI-3D) and new neutron cross-section evaluation data for materials of safety interest to EM, such as ${ }^{233} \mathrm{U}$. This technology and data were applied to examples of site-specific needs and problems identified by EM contractor NCS staff members. The value of the technology was demonstrated to personnel in the following areas: (1) for selecting NCS benchmarks to validate NCS computer codes and neutron data to assess applicability to NCS evaluations, (2) for developing safely subcritical NCS operating limits and approvals, (3) for identifying shortcomings or needs in nuclear data and/or critical experiment benchmarks, (4) for designing applicable experiment benchmarks, and (5) for determining computational biases and uncertainty as applied for establishing safe margins of subcriticality particular to EM processes and operations.

The specialized training in the use of the TSUNAMI-3D method for performing NCS code/data validation and NCS evaluations was also provided as an element of the technical support. The training was provided to each site's federal and contractor staff members (i.e., INL, RL, ORO and SRO).

EM NCS operational and programmatic on-site safety reviews and technical assessments were supported by ORNL NCS staff members and were conducted at the Richland, Savannah River, and Portsmouth Sites. These reviews identified findings, recommendations, and opportunities for improvement that point to regulatory and technical needs that if addressed, could contribute directly to accomplishing the accelerated risk-based cleanup and closure mission of EM.

Various EM NCS needs were identified during the four ORNL support activities. The activities revealed deficiencies (e.g., weaknesses and/or omissions) in NCS programmatic, regulatory, and technical areas. These deficiencies could call into question some historic NCS engineering judgments and evaluation bases, and as well as some NCS programs and compliance with regulatory specifications and expectations. Consequently, these deficiencies could interfere with or impede certain EM accelerated cleanup and closure missions. 



\section{TOPIC NEEDS IDENTIFIED AT DOE/EM WORKSHOPS}

The five workshops, titled "DOE/EM Workshop on Potential Nuclear Criticality Safety Evaluation Improvements for Operational Efficiencies," were cross-cutting for DOE and contractor NCS needs. The first workshop was conducted February 11-12, 2008, and provided cognizant DOE/EM federal and contractor NCS staff members the opportunity to self-identify potential programmatic, regulatory, operational, and technical improvement needs to ensure operational efficiencies. In all, 11 TNs were identified at the first workshop.

TOPIC NEEDS (TNs)—Specific Issues Initially Identified as Topic Needs with Work Group Leaders

\begin{tabular}{|c|l|l|}
\hline \multicolumn{1}{|c|}{ ID } & \multicolumn{1}{|c|}{ Topic/Need Description } & \multicolumn{1}{|c|}{ Lead Person(s) } \\
\hline TN-01 & $\begin{array}{l}\text { Inconsistencies between DOE Orders, Standards, and Guides result in } \\
\text { inefficiencies in implementation (e.g. 1027, 3009, 3007, 420.1B), and } \\
\text { clarity of expectations is lacking }\end{array}$ & $\begin{array}{l}\text { G. Christenbury (SRS) } \\
\text { F. Trumble (WSMS) } \\
\text { K. Kimball (Nisys) }\end{array}$ \\
\hline TN-02 & $\begin{array}{l}\text { Inadequate Criticality Safety Evaluations may lead to "stop work" and } \\
\text { inefficiencies }\end{array}$ & $\begin{array}{l}\text { B. Hawks (ORO) } \\
\text { A. Garcia (ID) } \\
\text { J. Morman (ANL) }\end{array}$ \\
\hline TN-03 & $\begin{array}{l}\text { Lack of support for mass characterization processes and lack of standards } \\
\text { create inefficiencies in controls and application }\end{array}$ & $\begin{array}{l}\text { L. Berg (HQ) } \\
\text { T. Hines (LEX) } \\
\text { J. Castor (BJC) }\end{array}$ \\
\hline TN-04 & $\begin{array}{l}\text { Lack of repository for NCS evaluations and data leads to re-generation of } \\
\text { analyses and re-creation of controls for common operations }\end{array}$ & L. Scott (SAIC) \\
\hline TN-05 & $\begin{array}{l}\text { Lack of standardized methodology for common NCS evaluations leads to } \\
\text { inefficiency and creates problems when material is transferred from one } \\
\text { location to another }\end{array}$ & $\begin{array}{l}\text { R. Wilson (HQ) } \\
\text { C. Cise (CWI) }\end{array}$ \\
\hline TN-06 & $\begin{array}{l}\text { Criticality detection and alarm methods are not tailored to the different } \\
\text { EM activities, which leads to confusion and possible excessive control of } \\
\text { the risk }\end{array}$ & $\begin{array}{l}\text { B. Hawks (ORO) } \\
\text { B. Rumble (Nisys) } \\
\text { K. Wessels (NFS) }\end{array}$ \\
\hline TN-07 & $\begin{array}{l}\text { Experiments and/or data need to enhance EM mission work and reduce } \\
\text { cost/schedule }\end{array}$ & $\begin{array}{l}\text { R. Wilson (HQ) } \\
\text { R. Westfall (ORNL) }\end{array}$ \\
\hline TN-08 & $\begin{array}{l}\text { Ineffective use of data from nonconformances, lessons learned, and } \\
\text { corrective actions leads to repetitive problems at EM sites }\end{array}$ & L. Berg (HQ) \\
\hline TN-09 & Contracting practices hinder effective criticality safety programs & $\begin{array}{l}\text { R. Wilson (HQ) } \\
\text { C.- F. Wu (HQ) }\end{array}$ \\
\hline TN-10 & $\begin{array}{l}\text { Retiring workforce and nuclear industry growth are creating deficiencies } \\
\text { in qualified staffing }\end{array}$ & $\begin{array}{l}\text { K. Wessels (NFS) } \\
\text { A. Prichard (PNL) }\end{array}$ \\
\hline TN-11 & $\begin{array}{l}\text { Funding, Resources, Contractor \& DOE Management Commitment, } \\
\text { Support, and Monitoring }\end{array}$ & $\begin{array}{l}\text { Wilson (HQ) } \\
\text { C.- F. Wu (HQ) }\end{array}$ \\
\hline
\end{tabular}

By the time the second workshop was conducted on June 13, 2008, staff members had addressed all of the identified needs for clarification and refinement. The third, fourth and fifth workshops were conducted on November 10, 2008, June 19, 2009, and November 20, 2009. Work products were defined for presentation at the second, third, fourth, and fifth workshops.

The status of each TN, as well as actions and products, was reviewed at the November 10, 2008, workshop, and at the subsequent workshops in 2009. Following the presentations about the status, attendees agreed upon future actions to address the TNs. The following is a discussion of the status of these actions and/or indications of the closure of certain of these TNs. 
Three of the eleven TNs have been addressed. Actions have been completed or defined by transmittals of white papers to EM management describing the specific deficiencies or issues that need to be addressed (see Appendix A, B, and C).

\begin{tabular}{|l|l|l|}
\hline \multicolumn{1}{|c|}{ ID } & \multicolumn{1}{|c|}{ Topic/Need Description } & \multicolumn{1}{c|}{ Lead Person(s) } \\
\hline $\begin{array}{l}\text { TN-03 } \\
\text { (App. A) }\end{array}$ & $\begin{array}{l}\text { Lack of support for mass characterization processes and lack of } \\
\text { standards create inefficiencies in controls and application }\end{array}$ & $\begin{array}{l}\text { L. Berg (HQ) } \\
\text { T. Hines (LEX) } \\
\text { J. Castor (BJC) }\end{array}$ \\
\hline $\begin{array}{l}\text { TN-06 } \\
\text { (App. B) }\end{array}$ & $\begin{array}{l}\text { Criticality detection and alarm methods are not tailored to the } \\
\text { different EM activities, which leads to confusion and possible } \\
\text { excessive control of the risk }\end{array}$ & $\begin{array}{l}\text { B. Hawks (ORO) } \\
\text { B. Rumble (Nisys) } \\
\text { K. Wessels (NFS) }\end{array}$ \\
\hline $\begin{array}{l}\text { TN-09 } \\
\text { (App. C) }\end{array}$ & Contracting practices hinder effective criticality safety programs & $\begin{array}{l}\text { R. Wilson (HQ) } \\
\text { C.- F. Wu (HQ) }\end{array}$ \\
\hline
\end{tabular}

\subsection{TN-03 (APPENDIX A)}

The workshop attendees concurred that the DOE should adopt Fissile Material Characterization as a Safety Management Program, with the objectives in terms of directives, standards, technology development, and quality assurance activities outlined in the white paper. Workshop participants also established a follow-on objective: Expand the Focus of the NDA White Paper Objectives Across All DOE Fissile Material Operations (Waste Management, Safeguards, NCS, etc.).

\subsection{TN-06 (APPENDIX B)}

The workshop attendees concurred that although the white paper for TN-06 had defined the needs of the NCS community needs an ANSI/ANS PINS (Project Initiation Notification System) form was needed for the revision of the ANSI/ANS-8.3-1997 standard, Criticality Accident Alarm System. Time and personnel effort will be needed to revise the standard. The initial step taken was as follows: The CAAS White Paper Sent to Shean Monahan, LANL and ANS-8.3 Chair, for Inclusion in PINS for ANS-8.3 Revision.

\subsection{TN-09 (APPENDIX C)}

The workshop attendees concurred that one objective in meeting TN-09 is to modify the DOE contracting processes to ensure the development and retention of NCS staff qualified for site applications. TN-09 was closed: The NCS Contracting Practices White Paper Was Sent to the Current DOE Contracts Manager.

\subsection{TOPIC NEEDS EXCLUDED FROM PROGRAM}

The workshop attendees confirmed that the following TN is not a complex-wide issue and should be removed from further consideration.

\begin{tabular}{|c|l|l|}
\hline ID & \multicolumn{1}{|c|}{ Topic/Need Description } & \multicolumn{1}{|c|}{ Lead Person(s) } \\
\hline TN-05 & $\begin{array}{l}\text { Lack of standardized methodology for common NCS } \\
\text { evaluations leads to inefficiency and creates problems when } \\
\text { material is transferred from one location to another }\end{array}$ & $\begin{array}{l}\text { R. Wilson (HQ) } \\
\text { C. Cise (CWI) }\end{array}$ \\
\hline
\end{tabular}


TN-08 has been deferred since a clear response was not evident.

\begin{tabular}{|c|l|l|}
\hline ID & \multicolumn{1}{|c|}{ Topic/Need Description } & \multicolumn{1}{c|}{ Lead Person(s) } \\
\hline TN-08 & $\begin{array}{l}\text { Ineffective use of data from nonconformances, lessons } \\
\text { learned, and corrective actions leads to repetitive problems at } \\
\text { EM sites }\end{array}$ & L. Berg (HQ) \\
\hline
\end{tabular}

\subsection{FUTURE WORK ON THE TOPIC NEEDS}

Topic Needs that have been defined but require identification for programmatic and fiscal support for further action and completion follow.

\begin{tabular}{|l|l|l|}
\hline \multicolumn{1}{|c|}{ ID } & \multicolumn{1}{|c|}{ Topic/Need Description } & \multicolumn{1}{c|}{ Lead Person(s) } \\
\hline $\begin{array}{l}\text { TN-01 } \\
\text { (App. D) }\end{array}$ & $\begin{array}{l}\text { Inconsistencies between DOE Orders, Standards, and } \\
\text { Guides result in inefficiencies in implementation (e.g. 1027, } \\
\text { 3009, 3007, 420.1B), and clarity of expectations is lacking }\end{array}$ & $\begin{array}{l}\text { F. Trumble (WSMS) } \\
\text { K. Kimball (Nisys) }\end{array}$ \\
\hline TN-02 & $\begin{array}{l}\text { Inadequate Criticality Safety Evaluations may lead to stop } \\
\text { work and inefficiencies }\end{array}$ & $\begin{array}{l}\text { B. Hawks (ORO) } \\
\text { A. Garcia (ID) } \\
\text { J. Morman (ANL) }\end{array}$ \\
\hline $\begin{array}{l}\text { TN-04 } \\
\text { (App. E) }\end{array}$ & $\begin{array}{l}\text { Lack of repository for NCS evaluations and data leads to re- } \\
\text { generation of analyses and re-creation of controls for } \\
\text { common operations }\end{array}$ & L. Scott (SAIC) \\
\hline $\begin{array}{l}\text { TN-07 } \\
\text { (App. F) }\end{array}$ & $\begin{array}{l}\text { Experiments and/or data are needed to enhance EM mission } \\
\text { work and reduce cost/schedule }\end{array}$ & $\begin{array}{l}\text { R. Wilson (HQ) } \\
\text { R. Westfall (ORNL) }\end{array}$ \\
\hline $\begin{array}{l}\text { TN-10 } \\
\text { App. G) }\end{array}$ & $\begin{array}{l}\text { Retiring workforce and nuclear industry growth are creating } \\
\text { deficiencies in qualified staffing }\end{array}$ & $\begin{array}{l}\text { K. Wessels (NFS) } \\
\text { A. Prichard (PNL) }\end{array}$ \\
\hline TN-11 & $\begin{array}{l}\text { Funding, Resources, Contractor \& DOE Management } \\
\text { Commitment, Support, and Monitoring }\end{array}$ & $\begin{array}{l}\text { R. Wilson (HQ) } \\
\text { C.-F. Wu (HQ) }\end{array}$ \\
\hline
\end{tabular}

\subsubsection{TN-01}

The perceived inconsistencies among DOE Orders, Standards, and Guides have been tabulated for final verification by DOE and contractor NCS community (see discussions in Appendix D). Future actions are making assignments for coordinating input to the DOE RevCom system and submitting proposed text for the documents. It has been suggested that text development and coordination of input to RevCom be broadened to include the balance of the DOE NCS communities [e.g., the Office of Nuclear Energy (NE), the Office of Science (SC), the Office of Civilian Radioactive Waste Management (RW), and the National Nuclear Security Administration (NNSA)]. At the June 19, 2009, EM workshop there was substantial discussion of the definition and application of the terminologies "nature of process" and "double contingency principle." It was noted that the writing group for ANS-8.1 is in the process of clarifying the definition of the double contingency principle. Responsibilities are being established for incorporation of the clarified terminologies in the revision of the identified documents through RevCom. The work group is coordinating with a DOE/EFCOG committee in proposing alternative regulatory language. The first projects are DOE-STD-1027 (ref. 2) and DOE-STD-3007 (ref. 3). 


\subsubsection{TN-02}

The historical, and possible future, inadequate CSEs that can lead to stopped work and inefficiencies require further attention. Some work involves the revision of DOE Orders, Standards, and Guides (TN01 ) but also requires that the group work toward a consensus in the development and execution of a training program for the preparation of NCSEs and analyses. At the June 19, 2009, workshop, Jim Morman, chair of the NCSP Criticality Safety Support Group (CSSG), discussed the elements of an effective modern CSE. He mentioned the current NCSD white paper on evaluations and the NCSP NCSET modules on the various elements of evaluations, as well as the NCSP plan to address the training aspect of evaluations in the near term. The white paper is complete and was issued at the November 2009 ANS meeting. The second work product was a revision to the NCSET educational module on CSEs which is available on the DOE NCSP web site. A presentation on this EM-sponsored project was made at the November 2009 workshop. A revised module and operational example have been developed and provided to the NCSP for posting on the web. The third project is two workshops on hazard analysis held for criticality safety practitioners at the June ANS meeting in San Diego. Responsibilities are being established for the coordination of the document revision process in TN-01 and the implementation of the new training program.

\subsubsection{TN-04}

To date, the effort to develop a reference repository for NCS evaluations and data has done little more than to identify potential sources and needs for information (see Appendix E). That repository is intended for use by practitioners to reduce the number of repetitive NCS evaluations performed or to provide starting references for needed evaluations_-somewhat like the International Handbook of Evaluated Criticality Safety Benchmark Experiments (IHECSBE). Complicating aspects of this endeavor include issues regarding security classification, business sensitivities, and proprietary information. The TN Lead Person and participating workshop attendees agreed that the potential impediments could prove cumbersome. Future work includes further identification of impediments and methods to address or circumvent them. At the June 19, 2009, workshop, Jim Felty, NCSP management, pointed out that the site points-of-contact, as shown in Appendix E, are to determine the level of participation by their site and serve as the contact person for the NCSP Evaluation Repository activities.

\subsubsection{TN-07}

With the assistance of DOE/EM-21 and DOE site/location and contractor NCS staffs, a substantial and comprehensive list of experiments and data needs was identified (see Appendix F). The challenge is the historical condition of available experiments and data to support NCS evaluations. Historically, experiments and data have focused on reactors (e.g., light water and fast breeder) and nuclear weapons designs. Those experiments and data omit information regarding materials and configurations of concern within EM mission work. Without pertinent experiments and materials information (e.g., decontamination, demolition, disposal/burial), NCS staffs must apply excessively restrictive assumptions within their evaluations, thereby negatively impacting the efficiency of operations (i.e., costs and schedules). Addressing this TN requires the identification of sponsors for the work. At the June 19, 2009, workshop, Brad Kerr of Parsons/SRS gave the status of ongoing discussions on new integral and differential data for the validation of titanium as a neutron absorber in the design qualification of the MST Salt-Waste Disposition process. At the November 2009 workshop, interested NCSP personnel continued to engage in discussing potential new measurements. 


\subsubsection{TN-10}

With the assistance of DOE site/location and contractor NCS staffs, the trends and needs for addressing the issue of retiring workforce and nuclear industry growth were surveyed (see Appendix G). DOE and contractor NCS staffs felt that a grass roots effort should be made to introduce potential newcomers to the field of NCS and that hiring/compensation adjustments are needed for DOE and contractors to compete with industry for NCS engineers. This TN working group continues to develop information and approaches to entice new engineers into the DOE complex. The working group also acknowledges that hiring and compensation issues are beyond the scope of their control. At the June 19, 2009, workshop, Jerry Hicks, DOE Albuquerque Operations (AL), suggested that the performance of in situ measurements be considered as a means of site-dependent NCS orientation. At the June 19, 2009, workshop, Adolf Garcia, DOE Idaho Operations (ID), proposed moving NCS skills into formal academic programs, supported by more grants and assistantships.

\subsubsection{TN-11}

EM-60 and EM-61 have provided assurances that funding resources, contractor and DOE management commitment, support, and monitoring are present to address NCS needs. To benefit from that support requires that the NCS community provide a clear identification of each need and a clear description of the benefit-to-cost value in addressing the need, the latter being difficult to accomplish.

All workshop attendees agreed that issues TN-07 and TN-11 are beyond the scope of DOE and contractor NCS staffs. Liaison with the NCSP technical elements is an important function of this program. Close cooperation is required to demonstrate benefit-to-cost value. 



\section{IDENTIFIED NEEDS ARISING FROM TECHNICAL SUPPORT, TRAINING, AND ASSESSMENT OF ON-SITE CONTRACTOR OPERATIONS}

As offered by ORNL and supported by DOE/EM-21 and contractor site personnel, ORNL provided specialized analytical technical support and training to contractor and federal staff at Idaho National Laboratory (INL), Hanford Site (RL), Oak Ridge Operations (ORO), and Savannah River Operations (SRO). The training involved recently developed analytical technologies as they specifically applied to the needs and problems of the on-site contractor NCS staffs. These technologies included the application of computational sensitivity and uncertainty analyses that were demonstrated to be useful for selecting and applying nuclear criticality safety benchmarks. These benchmarks were used to validate NCS computer codes and neutron data for developing safely subcritical NCS operating limits and approvals. The training included the determination of computational biases and uncertainty as applied to establish safe margins of subcriticality for specialized EM processes and operations.

\subsection{IDAHO NATIONAL LABORATORY}

\subsubsection{Analytical Technical Support and Training}

The NCS staff at INL had an interest in and need for justifying the rearrangement and optimization of storage arrangements in their IFSF. In August 2003, ORNL staff had provided general TSUNAMI Sensitivity/Uncertainty training to 10 participants at Idaho Falls. The INL staff had determined that few potentially relevant nuclear criticality benchmarks were applicable to the performance of computer code and neutron data validation and the determination of appropriate margins of subcriticality. The INL staff determined that the available benchmarks in the IHECSBE and the storage configurations of interest were dissimilar in nature as determined by conventional validation techniques [e.g., comparisons of atom ratios of hydrogen to fissile materials, material compositions, energy of average neutron lethargy causing fission (EALF)]. Also, none of the conventional validation techniques permitted the estimation of computed biases and uncertainties of NCS evaluations resulting from the neutron cross-section data and gaps in experimental information (e.g., proportions of fissionable to nonfissionable materials, as well as neutron moderation, leakage, and reflection producing dissimilar neutron energy spectra).

After the INL staff provided descriptions/models of the IFSF including the contained irradiated fuel types, ORNL performed new state-of-the-art/data computations [i.e., SCALE TSUNAMI-3D (ref. 4)] of the IFSF storage configurations. ORNL analytical support included the modeling of 13 fuel types in the square-pitched IFSF storage array configuration that was surrounded by thick concrete walls, floor, and ceiling. Neutron multiplication, $k_{\text {eff, }}$ sensitivities, and uncertainties were determined for the IFSF calculations. An additional 217 IHECSBE benchmarks were computed with TSUNAMI-3D. Following these computations and analyses, ORNL provided the INL staff with a training tutorial (April 2005, 15 participants) in the use of the new computational tools to examine and understand the primary influences on the safety evaluation of the IFSF. Conclusions from that expert technical assistance were as follows:

- Benchmark coverage/applicability for validating calculations of each individual fuel type is mixed.

- Although there are many different materials and factors (e.g., thorium, fission products, plutonium, degree of unknown moderation), as well as geometry influences on the IFSF, ${ }^{235} \mathrm{U}$ generates most of uncertainty.

- $\quad$ Not unexpectedly, damp Materials Test Reactor fuel had the highest ${ }^{235} \mathrm{U}$ sensitivities.

- Analyzed benchmarks provide excellent coverage for most of the important nuclide-reaction pairs in the IFSF. 
- Penalty analysis reveals that an additional $0.2 \% \Delta \mathrm{k} / \mathrm{k}$ margin would compensate for data uncertainties due to benchmark $k_{\text {eff }}$ sensitivities limitations relative to the IFSF sensitivities.

- Additional analyses with a more realistic model of IFSF would be beneficial but computationally intensive.

- The inclusion of additional benchmarks having materials of proportions used for IFSF validation would be beneficial.

- Certain neutron cross-section data for materials of interest would need to be available.

The TSUNAMI-3D models of the IFSF and the 217 IHECSBE benchmarks, as well as the TSUNAMI-3D code, were provided to the INL staff for their use.

\subsubsection{Nuclear Data}

A substantial portion of the NCSP nuclear data improvement program has been directed toward INL applications. Given the INL roles for disposition of stainless steel and graphite fuel elements in a wide variety of test and demonstration reactor configurations, data measurements and evaluations have been performed on ${ }^{232} \mathrm{Th},{ }^{233} \mathrm{U},{ }^{235} \mathrm{U},{ }^{238} \mathrm{U},{ }^{239} \mathrm{Pu},{ }^{240} \mathrm{Pu},{ }^{55} \mathrm{Mn},{ }^{53} \mathrm{Cr}$, natural chromium, ${ }^{58} \mathrm{Ni}$, and ${ }^{60} \mathrm{Ni}$.

Additional programs at INL benefiting from the nuclear data work include the Idaho Cleanup Project and the Advanced Mixed Waste Treatment Project. Their work involves conditioning the fissionable actinides for waste drum disposition. In addition to improved data for the actinides, improved data for container-storage and waste-dispositioning media (Fe, $\mathrm{O}, \mathrm{Si}, \mathrm{Ca}, \mathrm{K}, \mathrm{Al})$ are of benefit.

\subsubsection{INL Need(s):}

- It is likely that additional reinforcing tutorials on sensitivity/uncertainty methodology would be beneficial to the INL staff.

- Experiments are needed to benchmark U-Th light-water ${ }^{233} \mathrm{U}$ breeder reactor fuels in an epithermal to fast neutron spectra as would be found in dry storage and future disposal.

\subsection{HANFORD SITE}

\subsubsection{Analytical Technical Support and Training}

The NCS staff at Richland had an interest in and need for justifying the optimization of transuranic drum storage arrangements for transuranic wastes. Also, there is an ongoing interest in the characterization of plutonium, because it is stored in the large Hanford waste tanks. During the spring and summer of 2004, ORNL staff performed a series of sensitivity/uncertainty analyses on models of these applications as specified by the Hanford NCS staff. These studies are documented as ORNL Internal Memoranda, Charles O. Slater, Evaluation of the Similarities of Transuranic Waste Storage Configurations to Criticality Benchmark Experiments: Part 1-March 30, 2004, Part 2-April 21, 2004, and Part-3 June 15, 2004.

The studies of these applications were followed by the establishment of USLs with the use of the USLSTATS program and the results for 164 plutonium critical experiments. The follow-on study is documented as ORNL Internal Memorandum, Charles O. Slater, Upper Safety Limits for Several Applications Based on 164 Plutonium Experiments, September 22, 2004. For all of the applications, the 
limit USL-1 lies between $k_{\text {eff }}$ values of 0.9436 and 0.9440 , and USL-2 lies between 0.9809 and 0.9823 . The effective multiplication factors ( $k_{\text {eff }}$ values) for these applications at Hanford are found in the following table.

\begin{tabular}{lcc}
\hline \multicolumn{1}{c}{ Application } & $\boldsymbol{k}_{\text {eff }}$ & $\begin{array}{c}\text { Standard deviation } \\
\text { for } \boldsymbol{k}_{\text {eff }}\end{array}$ \\
\hline Hanford 12 $\times 12 \times$ 5 Drum Array & 0.9797 & 0.0006 \\
Hanford Single Drum & 0.8981 & 0.0002 \\
Infinite Planar Array of Drums with 485 g Pu per Drum & 0.8537 & 0.0002 \\
Infinite Planar Array of Drums with 195 g Pu per Drum & 0.5194 & 0.0002 \\
Hanford Conservative Waste Tank Model with 2.6 g/L Pu & 0.6000 & 0.0 \\
Hanford Representative Waste Tank Model with 2.6 g/L Pu & 0.5351 & 0.0 \\
\hline
\end{tabular}

Following these computations and analyses, ORNL provided the Hanford staff with a training tutorial (August-September 2004, 15 participants) in the use of the new computational tools to examine and understand the primary influences on these safety evaluations.

\subsubsection{Nuclear Data}

Another area of substantial support for Hanford has been in the NCSP nuclear data improvement program.

In the 2003 study that Jerry McKamy performed for EM-5, the following nuclear data needs were identified by the various EM programs at Hanford:

- Spent Nuclear Fuel Program-Fe, Cr, Mn, Ni, Cu, and fission products;

- Plutonium Finishing Plant-Cl, Fe, Ni, Mn, Cr, Si, Ce, and Ca;

- Waste Management Program-Fe, Ni, Cr, and Mn,

- Tank Farms-Fe, Mn, Cr, Ni, Ca, and Cl;

- fuel storage-Fe, Ni, Cr, and $\mathrm{Mn}$;

- legacy facilities-Fe, Ni, Cr, and Mn.

In the intervening years, the NCSP has supported new measurements and evaluations that include many of these elements. For example, the $\mathrm{Fe}, \mathrm{Cr}$, $\mathrm{Ni}$, and $\mathrm{Mn}$ components of stainless steel now have improved data, as do Cl and Si. In September 2006, an ORNL staff member met with Hanford NCS specialists and discussed this progress. The presence of $\mathrm{Ce}, \mathrm{Ca}$ and $\mathrm{Cu}$ in the spent fuel and plutonium waste streams was discussed. Data needs for these materials have been conveyed to the NCSP Nuclear Data Advisory Group. Measurements and evaluations have been scheduled in the NCSP Five-Year Plan.

\subsubsection{Hanford Need(s)}

Further improvements are needed in these areas:

- Better differential data are required for $\mathrm{Cu}, \mathrm{Ce}$, and Ca for applications in the Spent Nuclear Fuel Program and the Plutonium Finishing Plant.

- The behavior of Fe, Gd, and Pu in the new DWPF for plutonium conditioning and dispositioning in glass requires further investigation.

- There are continuing needs for integral validation data (both subcritical and critical experiments) that simulate the neutronics in layered combinations of fissionable and processing materials. 


\subsubsection{Hanford Operational Assessment}

As part of their membership in the NCSP CSSG, NCS staff at ORNL assisted DOE-EM in the technical assessment of the Hanford Waste Treatment Plant (WTP) Criticality Safety Evaluation Report (CSER) on December 9-11, 2008 (ref. 7) and the Criticality Safety Technical Basis for Tank Farm Operations (TFO) on December 7-11, 2009 (ref. 8). The latter assessment included review of a technical issue associated with future receipt and sampling of TFO materials at the WTP. The criteria for the onsite operational NCS review were taken from DOE Orders (e.g., DOE O 420.1A/B), Guides, and Standards (e.g., DOE-STD-1158-2002), DOE-referenced ANS consensus standards (i.e., ANSI/ANS-8), and expert technical competencies.

Results from the 2008 WTP assessment included five Recommendations, nine Opportunities for Improvement, and two Positive Practices. Results from the 2009 TFO assessment included ten Recommendations, five Opportunities for Improvement, and two Positive Practices. The 2009 assessment also included two Recommendations for WTP.

\subsection{OAK RIDGE OPERATIONS (ORO)}

\subsubsection{ORNL Radiochemical Development Facility (Isotek Operations)}

\subsubsection{Analytical Support and Consultation}

Recently, ORNL staff performed an extensive evaluation of ${ }^{233} \mathrm{U}$ integral experimental data with regard to its suitability in the validation of the neutronics methodology being applied in the criticality safety evaluation of Isotek operations. This study is documented in an ORNL report: Application of the SCALE TSUNAMI Tools for the Validation of Criticality Safety Calculations Involving ${ }^{233} U$, ORNL/TM-2008-196 (ref. 5).

As characteristic of fissile material processing involved in projected Isotek applications, four idealized configurations were studied:

- Application 1-A $12.2 \mathrm{~cm}$ radius sphere containing $220 \mathrm{~g} / \mathrm{L}{ }^{233} \mathrm{U}$ nitrate solution, reflected by $0.25 \mathrm{~cm}$ of SS-304 and $2 \mathrm{~cm}$ of water. This system has a calculated $k_{\text {eff }}$ of 1.0028 and an EALF of $0.282 \mathrm{eV}$; that is, it is a thermal neutron system.

- Application 2-A $14 \mathrm{~cm}$ radius sphere containing the Consolidated Edison Uranium Solidification Project (CEUSP) fuel as $220 \mathrm{~g} / \mathrm{L}$ uranyl nitrate solution, again reflected by $0.25 \mathrm{~cm}$ of SS-304 and $2 \mathrm{~cm}$ of water. CEUSP isotopics (in weight percent) are ${ }^{233} U(9.7),{ }^{234} U(1.4),{ }^{235} U$ (76.5), ${ }^{236} U$ (5.6), and ${ }^{238} U$ (6.8). This system has a calculated $k_{\text {eff }}$ of 0.9889 and an EALF of $0.121 \mathrm{eV}$. Thus, the sphere is somewhat softer than that in Application 1.

- Application 3-A $53 \mathrm{~cm}$ radius sphere containing $600 \mathrm{~g} / \mathrm{L}$ uranyl nitrate solution, again reflected by $0.25 \mathrm{~cm}$ of SS-304 and $2 \mathrm{~cm}$ of water. For this more-concentrated solution, the uranium isotopics (in weight percent) are ${ }^{233} U(3.0),{ }^{235} U(0.2)$, and ${ }^{238} U$ (96.8). This system has a calculated $k_{\text {eff }}$ of 0.9690 and an EALF of $0.0631 \mathrm{eV}$. As a much larger sphere containing a lowenriched solution, it is somewhat softer still than that in either Application 1 or Application 2.

- Application 4-This system is a storage array of the CEUSP uranium powders with (atom ratios) of hydrogen (H/U 0.21), oxygen $(\mathrm{O} / \mathrm{U} 3.1)$, and carbon $(\mathrm{C} / \mathrm{U} 4.7)$. The fuel is stored vertically in canisters loaded into carbon steel pipes that are situated in an array of concrete tubes surrounded by external concrete reflection/shielding. The system has a calculated $k_{\text {eff }}$ of 0.751 and an EALF of $2.63 \mathrm{eV}$. Thus, it represents the CEUSP fuel as feed material stored in an epithermal system, as opposed to Application 2, which represents the dissolved CEUSP fuel of some stage of conditioning/processing. 
In addition to these four applications, 672 critical experiments were evaluated with the TSUNAMI/TSURFER sensitivity/uncertainty software to test their similarity to these applications. The 672 experiments are documented as benchmarks in the IHECSBE. They included 232 experiments fueled with ${ }^{233} \mathrm{U}, 28$ experiments fueled with mixed uranium and plutonium, and the balance fueled with ${ }^{235} \mathrm{U}$. These included 255 low-enriched uranium (LEU) systems (LEU $<10 \%{ }^{235} \mathrm{U}$ ), 4 intermediate-enriched uranium (IEU) systems and 153 highly enriched uranium (HEU) systems (HEU > 60\% ${ }^{235} \mathrm{U}$ ).

An extensive series of results for the four applications, as well as the tests for similarity with the 672 critical experiments are well documented. The results include the following:

- Major total sensitivity profiles are documented for the important isotopes in each of the four applications.

- Uncertainties are noted in the application $k_{\text {eff }}$ values due to cross-section covariance data for the top six contributors in terms of nuclide and reaction type: for example, ${ }^{233} \mathrm{U}$ fission.

- Uncertainty data for the most significant nuclide-reaction pairs for ${ }^{233} \mathrm{U},{ }^{235} \mathrm{U},{ }^{238} \mathrm{U}$, hydrogen, oxygen, and ${ }^{56} \mathrm{Fe}$ are plotted.

- A three-dimensional plot of the covariance data for the ${ }^{233} U$ neutron parasitic capture reaction has been documented.

- For each of the four applications, there is a plot of the similarity index values for the 672 critical experiments; sensitivity profile comparisons for nuclide-reaction pairs important to the applications and pertinent experiments; summary tables of top contributors to similarity data for nuclide-reaction pairs in pertinent experiments; and an overall similarity summary for the 672 experiments in tabular form, with a graduated listing of the similarity index range: $<0.1$ to $>0.95$ and $<1.0$.

These results were followed with an evaluation of the upper subcritical limits (USLs), utilizing the USLSTATS code for EALF trending and demonstrating bias and the TSURFER data adjustment code for demonstrating bias uncertainty due to the cross-section covariance data.

The major conclusions of the ORO/Isotek study are as follows:

- Similarity assessments identified a large number of experiments that could be used for the validation of Applications 1 and 2 (thermal systems driven by ${ }^{233} \mathrm{U}$ and CEUSP fuel), but no experiments were found to be adequately similar for Application 3 (well-thermalized concentrated solution of $3 \%{ }^{233} \mathrm{U}$ ) or Application 4 (epithermal system of CEUSP powders in a storage array). The last need relates to ORO-3, in Appendix F, TN-07, "U-233 in Intermediate Neutron Energy Spectra, Integral Data Development.”

- USLs were determined for all four applications using data adjustment techniques. These limits provide the margins needed to address uncertainty in the computational method which results, primarily from nuclear data uncertainties.

- Some discussion was provided as to possible approaches that could be used to address validation in situations where an adequate set of critical experiments was not available to validate applications. This relates to ORO-4 in Appendix F, TN-07, "U-233 in 11 Critical Assemblies, New SCALE Technologies, and MCNP Models and Cross Sections.”

It should be noted that this study was cosponsored by funding from EM-20 and from the NCSP managed by NA-117. Recent history of the DOE U-233 Program has included responsibilities for all three offices: NNSA, NE, and EM 


\subsection{EAST TENNESSEE TECHNOLOGY PARK (ETTP)}

\subsubsection{Analytical Support and Consultation}

ORNL NCS staff consulted with ETTP and ORO safety management and staff on the technical aspects of the NDA approach in the evaluation of uranium product holdup and deposits.

The following issues were addressed:

- $\quad$ inherent ${ }^{234} \mathrm{U}$ neutron source strength as a function of product history,

- neutron transport through the product/containment available for NDA detection, and

- product quantity/geometry interpretation and estimates from NDA detection.

Direct support in these areas from ORNL staff was summarized in the following presentation by Kevin D. Kimball and Ian C. Gauld: "Impact of NDA Uncertainties on NCS at the K-25 Site," presented at the June 2009 ANS meeting. An overall uncertainty of $10 \%$ was developed for the ${ }^{235} \mathrm{U} /{ }^{234} \mathrm{U}$ mass ratio, and the effect of uranyl oxyfluoride hydration on neutron emission rates was investigated with quantitative examples.

Various other areas of technical support have been brought into this consultation. For example, at the June 2009 EM Workshop, ORNL facilitated a presentation on the latest technology of Canberra Associates for NDA interpretation. As discussed previously (as part of TN-03) and in Appendix A, fissile mass characterization is being addressed under a defense board response as a separate effort chaired by Larry Berg, DOE/HQ.

There is an ongoing action item: 19 June 09-01, Expand the Focus of the White Paper Objectives Across All DOE Fissile Material Operations (Waste Management, Safeguards, NCS, etc.).

\subsection{PORTSMOUTH GASEOUS DIFFUSION PLANT (PORTS)}

\subsubsection{Portsmouth Operational Assessment}

ORNL NCS staff assisted EM-21 in the technical evaluation of the Portsmouth NCSP. Results from that assessment included three Findings, two Recommendations, and four Opportunities for Improvement. The criteria for the on-site operational NCS reviews were taken from DOE Orders (e.g., DOE O 420.1A/B), Guides, and Standards (e.g., DOE-STD-1158-2002), DOE-referenced ANS consensus standards (i.e., ANSI/ANS-8), and expert technical competencies.

\subsubsection{Findings}

- The NCSP conducted by the EM contractor, LATA/Parallax Portsmouth (LPP), does not adequately evaluate the upset conditions associated with characterization processes and does not provide adequate guidance or oversight for the selection and implementation of characterization methods used to determine fissile material mass. LPP must ensure that appropriate technical expertise is used to evaluate all characterization techniques used to meet NCS ${ }^{235} \mathrm{U}$ mass limits. The NCSE should restrict the use of characterization methods to those that have been evaluated by NCS or have met the measurement performance requirements.

- The NCS oversight committee was not functioning.

- Drum arrays did not meet requirements.

\subsubsection{Recommendations}

The following actions were recommended: 
- Correct design deficiencies associated with tamper-indicating tape.

- Provide root cause determination of collection of similar NCS nonconformances and develop corrective action.

\subsubsection{Opportunities for Improvement}

The following actions were determined to be Opportunities for Improvement:

- Improve NCS posting simplicity and clarity to improve adherence to posted controls.

- Add hazard identification methods (scenario development) to the qualification requirements for criticality safety staff.

- Develop and implement processes for resolving differences in characterization data needs.

- Provide hazard evaluation processes in NCS evaluations and determinations that are sufficient to allow independent review.

\subsubsection{Portsmouth Need(s)}

- DOE and contractor NCS staffs need further education and training in the development of NCSEs and in determining and correcting root cause issues (TN-02).

- Contractor management needs further education in their responsibilities for NCS programs (TN-02).

- Contractor operations personnel need further education and training in specifying and utilizing NCS controls (TN-08).

- Improved waste matrix NDA methods and analyses are required (TN-03).

\subsection{SAVANNAH RIVER OPERATIONS (SRO)}

\subsubsection{SRS Operational Review, Analytical Technical Support, and Training}

ORNL NCS staff joined EM-21 staff in conducting the on-site operations and program review of the SRS. Operations reviewed included those in which a plutonium waste stream was considered for control by a soluble gadolinium absorber in levels of neutron moderation varying from thermal (liquid media) to epithermal (glass media).

One result of the study was the generation of new uncertainty data for use in the qualification of potential operations involving gadolinium. These data are now available to the NCS community with the recent release of ENDF/B-VII.

A second result of the study involved the evaluation of neutron absorption by titanium as MST in the extraction of actinides in the salt-waste treatment process. For this application, improvement in the titanium cross-section uncertainty resulted in a reduction in the uncertainty in the subcritical margin from $\sim 4 \% k_{\text {eff }}$ to less than 1\% (ref. 7). In addition to enhanced understanding of the variation of $k_{\text {eff }}$ with system parameters, the performance of validating critical experiments with titanium is being explored.

As part of these computations and analytical studies, ORNL provided 15 participating SRS staff members with training tutorials in the use of the computational tools to examine and understand the primary influences on these safety evaluations (August 2004, Gadolinium/Plutonium Studies and May 2008, TSUNAMI Refresher, Titanium Uncertainty Studies). 


\subsubsection{Savannah River Site Need(s)}

Further information is needed in the following areas:

- $\quad$ actinide adsorption onto MST;

- behavior of Fe, Gd, and Pu in the DWPF melter;

- $\quad$ solubility of gadoliniumin nitric/formic acid;

- analysis of plutonium in glass for the DWPF melter.

Experiments are needed to investigate the following topics:

- $\quad$ titanium in thermal neutron spectra;

- $\quad$ sodium in thermal neutron spectra;

- $\quad$ plutonium in glass DWPF spectra with absorbers (i.e., Fe, Gd, Na, Mn, B, Si); and

- molybdenum in a thermal neutron spectra as uranyl nitrate solution. 


\section{SUMMARY OF RESULTS OF THIS NEEDS ASSESSMENT}

\subsection{TECHNOLOGY NEEDS}

The objectives laid out in the EM NCS technology needs survey performed by Jerry McKamy in 2002 have been largely met. Neutron cross-section data, along with uncertainties, for a number of EM applications have been improved. Work continues on some nuclides specific to EM projects (e.g., copper, calcium, cerium). Partially through EM support, the sensitivity/uncertainty methodology has been brought to the production level and released for public use in the SCALE 6.0 system. Training in the use of the SCALE 6.0 sensitivity/uncertainty methods and data has been performed at the major EM sites: Hanford, INL and SRS and at ORO/EM operations. This training included demonstrations on substantial applications from these sites.

However, 32 new NCS technology needs were identified in the 2008 EM survey performed as TN-07 of the EM NCS workshops. These needs are summarized in Appendix F of this report.

In addition to integral experiments required to validate EM applications, additional needs exist in the areas of nuclear chemistry data, improved NDA technologies, and advanced transport methods for planning and qualifying CAASs. Some scoping-design and planning effort for experiments to address these new objectives has been performed. The results of this effort have been reported at the EM NCS workshops and, in some cases, incorporated into NCSP program planning.

\subsection{OPERATIONAL NEEDS}

From the perspective of NCS improvements in the EM fissile material operations, ten areas of endeavor were identified as being TNs at the initial February 2008 EM NCS workshop. Subsequently, work groups addressed each TN; investigated the scope of the issues; and made recommendations at the four additional EM NCS workshops, which were conducted on a semiannual basis. The work group reports to the EM NCS workshops are included as appendices to this report. The status of each TN is briefly summarized here.

\subsubsection{Regulatory Inconsistencies and Implementation Problems}

This work group has surveyed each DOE site and contractor for information on practical problems caused by DOE regulations. The survey was discussed at the follow-on meetings, and proposed solutions were developed. The work group is coordinating with a DOE/EFCOG committee in proposing alternative regulatory language. The first projects are STD-1027 and the interface STD-3009/ STD-3007.

\subsubsection{Inadequate Criticality Safety Evaluations}

This work group reviewed the site problems and work stoppages caused by poor evaluations and determined that the path forward should be educational for practicing criticality safety engineers. The first work product was a new white paper on developing CSEs to be issued by the NCSD of ANS. The paper was issued at the November 2009 ANS meeting. The second work product was a revision to the NCSET educational module on CSEs located on the DOE NCSP web site. The third project is two workshops on the topic of hazard analysis held for criticality safety practitioners at the June ANS meeting in San Diego and the November ANS meeting in Las Vegas. 


\subsubsection{Weak Fissile-Mass Characterization Programs}

This work group determined that DOE was developing a program to address part of the problem and decided a white paper on the issue was needed. The white paper was produced, approved by the EM NCS Workshop attendees, and provided to EM management and the DOE Non Destructive Analysis work group.

\subsubsection{Complex-Wide Repository for NCS Evaluations}

This work group was subsumed by the DOE NCSP, which already has a documents repository. The program has worked out the ground rules for this venture and now has the objective of collecting the titles of NCSEs from each DOE site. The approach is to have a site contact person provide a list of titles for NCSEs that may be of interest to practitioners in the NCS community.

\subsubsection{Lack of Standardized Criticality Safety Evaluations for Transportation Applications}

This work group surveyed the DOE sites and determined that the extent of the problems did not warrant significant effort. Thus, this project was closed.

\subsubsection{Criticality Detection and Alarm Systems}

This workgroup developed a white paper on the problems of maintaining the CAASs detailed in the regulations. Included are suggested ways for the department to approve appropriate exemptions. The white paper was provided to DOE staff that had NCS oversight responsibilities.

\subsubsection{Survey of Technology Needs}

See Appendix F.

\subsubsection{Ineffective Use of Nonconformance Data and Lessons Learned}

This work group could not determine appropriate actions to address the issue but did determine it was a significant DOE-wide problem. The topic remains open for possible future work.

\subsubsection{Problems that Recent DOE Contracting Practices Have Engendered on Criticality Safety Practice}

The work group determined that their only possible action was to describe the problem. A white paper was written, reviewed by the EM NCS workshop participants, and provided to EM management.

\subsubsection{Problem of Contractor NCS Staffing and Staff Retention}

With the assistance of DOE site/location and contractor NCS staffs, the trends and needs associated with the retiring workforce and nuclear industry growth were surveyed (see Appendix G). The working group also acknowledged that the hiring and compensation issues are beyond the scope of their control. A white paper was written, reviewed by the workshop attendees, and provided to the participants. 


\section{REFERENCES}

1. J. McKamy, Analysis of Nuclear Criticality Safety Technology Supporting the Environmental Management Program, May 2002.

2. Department of Energy, DOE-STD-1027-92, Hazard Categorization and Accident Analysis Techniques for Compliance with DOE Order 5480.23, Nuclear Safety Analysis Reports, December 1992, Change Notice No. 1, September 1997.

3. Department of Energy, DOE-STD-3007-93, Guidelines for Preparing Criticality Safety Evaluations at Department of Energy Non-Reactor Nuclear Facilities, November 1993, Change Notice No. 1, September 1998.

4. B. T. Rearden, TSUNAMI-3D: Control Module for Three-Dimensional Cross-Section Sensitivity and Uncertainty Analysis for Criticality, SCALE: A Modular Code System for Performing Standardized Computer Analysis for Licensing Evaluation, ORNL/TM-2005/39, Version 5.1, Volume 1, Book 2, Sect. C9, Oak Ridge National Laboratory, Oak Ridge, Tenn., November 2006.

5. D. E. Mueller, B. T. Rearden, and D. F. Hollenbach, Application of the SCALE TSUNAMI Tools for the Validation of Criticality Safety Calculations Involving ${ }^{233} U$, Oak Ridge National Laboratory, Oak Ridge, Tenn., January 2009.

6. L. Leal, R. Westfall, D. Eghbali, and F. Trumble, "Assessment of Titanium Cross Sections and Uncertainties for Application in Criticality Safety,” Proc. 8th International Conference on Nuclear Criticality Safety, Vol. 2, St. Petersburg, Russia, June 1, 2007, p. 50.

7. R. E. Wilson et al., DOE Criticality Safety Support Group Review of the Waste Treatment and Immobilization Plant (WTP) Preliminary Criticality Safety Evaluation Report (CSER), DOE-HQ, EM-60, December 2008.

8. R. E. Wilson et al., DOE Criticality Safety Support Review of the Washington River Protection Solutions Tank Farm Operating Contractor Criticality Safety Basis, DOE-HQ, EM-20, December 2009. 

APPENDIX A

TN-03 



\section{APPENDIX A}

TN-03

\section{ESTABLISHMENT OF FISSILE MATERIAL CHARACTERIZATION AS A SAFETY MANAGEMENT PROGRAM}

Problem: Lack of well-defined DOE requirements for mass characterization processes supporting Nuclear Criticality Safety (NCS) programs creates potential inadequacies in implementation of NCS controls.

\section{RECOMMENDATION}

DOE should establish programmatic safety requirements (within DOE directives) for fissile mass and isotopic characterization processes used to support NCS programs. The most direct method for establishing the necessary programmatic safety requirements is to modify similar existing requirements used to support environmental protection programs and apply them within nuclear safety programs. The DOE Consolidated Audit Program (DOECAP) currently has a quality systems document that supports the certification of analytical laboratories in support of environmental protection programs. Modification of the DOECAP quality systems document to include the programmatic safety requirements for NCS programs is a logical progression. The modified quality systems document would provide the quality assurance requirements for the implementation of characterization programs that support nuclear criticality safety programs. Assurance that the requirements are adequately implemented could be accomplished by using the DOECAP process to certify laboratories and nondestructive assay (NDA) programs (as is currently being done for environmental protection programs).

\section{BACKGROUND}

NCS programs establish controls and limits based on the anticipated and measured distribution and quantities of fissile isotopes. NCS controls and limits are then implemented by operational personnel. The ability of a facility to obtain accurate and reliable characterization data has a significant impact on its capability to generate and comply with NCS requirements. There are two general programs available to generate characterization data (fissile isotope concentration and mass). Analytical programs are typically used to characterize quantities of radioactive isotopes that are amenable to being sampled (i.e., the sample is retrievable and representative of the material being measured). NDA programs are used to supplement or direct analytical efforts or for cases in which sampling is not practical or feasible.

The degree of reliance of NCS programs on fissile material characterization programs is difficult to overstate. Regardless of the margin of safety built into NCS limits and controls, determining the accuracy and reliability of methods used to generate material characterization data is essential. NCS programs require that the "bounding" value for characterization data be used to ensure NCS limits are met. The bounding value for fissile material characterization data is obtained by adding the uncertainties associated with characterization activities to the measured value. In addition, the potential failure modes of characterization processes must be adequately defined and evaluated by the NCS program. The evaluation of the characterization data is required to ensure that methods used to 
implement NCS controls are sufficiently reliable and that no single error creates conditions that could lead to a criticality accident.

The determination of uncertainties associated with characterization processes consists of two primary elements: (1) precision (random error) and (2) bias (systemic error). Precision is affected by counting times, equipment capabilities, etc. Bias is affected by equipment design, sampling techniques, calibration methods, etc. Characterization programs are typically well versed in providing bounds on the precision of the characterization techniques. However, the bias associated with characterization techniques is frequently not as readily quantified or understood. The identification of potential characterization failure modes must be identified and addressed by NCS programs. Characterization failures with a negative effect on NCS program implementation include misidentification of fissile material as nonfissile and underestimation of fissile mass. Examples of failure modes include

- the use of incorrect assumptions in calculation models used to interpret NDA data (wrong chemical form assumed),

- assignment of data results to the wrong container (labeling error)

- incorrect assignment of attenuation constant (estimation of shielding thickness incorrect), and

- assumptions related to distribution of materials.

Defense Nuclear Facility Safety Board (DNFSB) Recommendation 2007-01 identified weaknesses in in-situ NDA measurement programs used to support NCS program implementation. DOE has developed an implementation plan to address the DNFSB recommendation. The elements of DNFSB Recommendation 2007-1 include the following needs: the establishment of requirements and guidance focusing on nuclear safety limits, the application of standard protocols and methodologies, assessments to ensure that NDA programs are using the best available technology, and incorporation of appropriate quality assurance elements into in-situ NDA measurements when the measurements are used for compliance with nuclear safety limits.

The DOE NCS community has likewise identified a lack of well-defined DOE requirements for mass characterization processes supporting NCS programs. A DOE NCS working group is recommending that DOE establish facility and programmatic safety requirements for fissile mass and isotopic characterization processes used to support NCS programs (the topic of this paper).

The standardization of requirements through the DOECAP quality systems document and the associated DOECAP assessment process would provide a means of correcting the deficiencies in the critical area of defining the accuracy and reliability of characterization programs. DOECAP has a quality systems document that provides the minimum requirements for implementing and assessing analytical services that support environmental protection programs. DOECAP is a DOE assessment program managed by the DOE Office of Health Safety and Security (HSS). DOE relies upon on DOECAP to certify that laboratories have the capability in terms of equipment, procedures, and personnel to provide quality data in support of environmental protection programs. 
APPENDIX B

TN-06 



\section{APPENDIX B}

TN-06

\section{WHITE PAPER ON FUTURE CAAS APPLICATIONS DURING D\&D AND OTHER SPECIAL SITUATIONS}

\section{INTRODUCTION}

During the EM Conference on Nuclear Criticality Safety (NCS) in February 2008, the Contractor Operations and NCS Engineers expressed concerns in regards to the need for more flexibility in applying criticality detection/notification instrumentation during major D\&D efforts facing many of the Department of Energy (DOE) sites. The DOE is interested in reviewing the Contractor's criticality detection requirements during $\mathrm{D} \& \mathrm{D}$ and the Contractor's recommended solutions and justifications. From this information, DOE NCS personnel will evaluate the solutions and provide guidance and approvals for the future applications for criticality detection/notification. This white paper will provide some Contractor recommendations that would help during gaseous diffusion plant D\&D and could also be applied to other special situations and at other DOE sites.

\section{BACKGROUND}

During plant operations, the Contractor and DOE have evaluated and approved the Criticality Accident Alarm Systems and their placement. The detectors meet the DOE regulations and American National Standards Institute (ANSI)/American Nuclear Society (ANS)-8.3, Criticality Accident Alarm System and are placed in process areas, through shielding calculations or other appropriate analysis, to ensure that there are no barriers to immediate detection and notification of a criticality accident.

\section{$\underline{\text { DOE Requirements }}$}

Assuming that the plant being decommissioned will fall under DOE Order 420.1B, the basic elements and control parameters of NCS programs shall satisfy the requirements in the ANSI/ANS Standards with several exceptions. The Order states the following:

- 3a (e) - Assessment of the need for and installation of criticality accident alarm and detection systems where appropriate to conform with paragraphs $3 \mathrm{~b}(2)$ and 3b (3) of this chapter.

- $3 b(2)$ - Criticality Safety Programs (CSPs) must satisfy the requirements of the revisions to consensus nuclear criticality safety standards of American National Standards Institute (ANSI)/American Nuclear Society (ANS) 8 in effect as of the date of this Order, unless otherwise modified or approved by DOE.

- $3 b$ (3) - All recommendations in applicable ANSI/ANS standards must be considered, and an explanation provided to DOE through the CSP description document whenever a recommendation is not implemented.

Simply stated, the DOE requires the following:

- Compliance with any updates/revisions to the ANSI/ANS Standards for criticality alarm systems unless DOE approves otherwise.

- All recommendations ("should” statements) in the ANSI/ANS Standards for criticality alarm systems shall be treated as requirements ("shall” statements) unless DOE approves otherwise. 
Under current DOE requirements, the contractor is allowed to propose an alternate strategy for control of the high worker hazard due to a criticality that deviates from ANSI/ANS 8.3 permanent CAAS criteria for D\&D activities. The alternate strategy must be clearly and thoroughly laid out including the proposed suite of controls, why the proposed risk posture is the most appropriate for the specific condition, and adequate justification for why the DOE should accept the alternate control strategy.

The Contractor's CSP description document and the facility's safety basis documents shall provide any exceptions to the above DOE requirements and explain the alternate strategy as described above. The CSP and the safety basis documents shall be approved by DOE

\section{ANSI/ANS-8.3 1997, Criticality Accident Alarm System}

"Where a criticality accident may lead to an excessive radiation dose, it is important to provide a means of alerting personnel and a procedure for their prompt evacuation or other protective actions to limit their exposure to radiation." (An excessive radiation dose is defined as "any dose to personnel corresponding to an absorbed dose from neutrons and gamma rays equal to or greater than 12 rad (0.12 Gy) in free air.”)

ANSI/ANS-8.3 includes the following applicable CAAS requirements:

- Evaluation of need for CAAS is required for all activities in which inventory in individual unrelated areas exceeds $700 \mathrm{~g}^{235} \mathrm{U}$.

o Individual areas may be considered unrelated when the boundaries between the area are such that there can be no uncontrolled transfer of material between areas

0 the minimum separation between materials in adjacent areas is $10 \mathrm{~cm}$ and the areal density of fissile material averaged over each individual area is less than $50 \mathrm{~g} / \mathrm{m}^{2}$.

- Criticality alarm signals shall be for prompt evacuation or other protective actions. The signals shall be distinctive and uniform through the system.

- The signal generators shall be automatically and promptly actuated upon detection of a criticality accident and continue to function as required by emergency procedures.

- The audio generators should produce an overall sound pressure level of at least $75 \mathrm{~dB}$ but not less than $10 \mathrm{~dB}$ above the maximum ambient noise level. (When necessary, visual signals or other alarm means should be considered)

- Where portable instruments are used, the usage shall be evaluated to determine appropriate criteria of this standard and criteria shall be specified in procedures.

- $\quad$ System shall be

o reliable,

o minimally vulnerable to damage or system failure,

o seismically tolerant,

o designed to provide failure warning, responsive (within 0.5 second of detector recognition of a criticality), and

o responsive to the minimum accident of concern.

\section{DISCUSSION}

There are two main discussion points in this white paper: what alternatives of criticality detection/notification will be allowed for the different circumstances that arise during D\&D and what requirements will be needed to ensure that CAAS removal is performed in an appropriate manner. 


\section{CAAS Alternatives during D\&D}

Most DOE site process areas have fixed CAAS meeting ANSI-ANS-8.3 with communication capabilities with a central control facility. This has been standard practice for over 40 years and has served the sites well. In addition, "Portable" Criticality Accident Alarm Systems (PCAAS) have supplemented fixed CAAS to allow work to continue during a short term CAAS outage for maintenance or to ensure proper annunciation during activities. The PCAAS is essentially the same design as fixed CAAS detector units but typically do not have communication capability with a central control facility. Because verification of operability cannot be performed at a central control facility, other "compensatory actions" are required, such as a verification of operability upon facility entry and periodically thereafter.

Additionally, the use of personal alarming dosimetry is used under special circumstances. They are used in the same circumstances that the PCAAS units as described above, during high noise operations that would jeopardize audibility during a CAAS/PCAAS alarm, or in instances where small areas of a facility may not have compliant CAAS coverage due to shielding.

The use of PCAAS and personal alarming dosimetry is generally avoided except where supplying a fixed CAAS system is not feasible and/or is extremely costly for the small benefit. With the improved technology and the ability to calibrate and affirm reliability of the portable devices, there should be broader acceptance of their use in D\&D and other circumstances.

Recommended approaches to obtaining acceptance of portable devices include:

- DOE can establish criteria for temporary system(s), redundancy, and remote monitoring, and generate a general guidance document. [Note: Guidance document (s) can be generated by one of the following depending on the desired level of need: (1) HSS, if overall complex desires guidance; (2) individual Program Office, example EM-1, if only EM sees a need; or (3) individual Site Office (e.g. PPPO) if only a few individual sites see the benefit or need, they can issue guidance for their specific contractor.]

- The Contractor can develop clear criteria and procedures for utilizing PCAAS and/or personal alarming dosimetry where there is a short-term (e.g., < 30 days) need (planned work, maintenance on fixed units, or NCS non-compliances). The criteria should be located in the Contractor's Nuclear Criticality Safety Program Description Document which requires DOE approval per DOE Order 420.1B and in the respective Documented Safety Analysis/Technical Safety Requirement Document(s) which also get DOE approval.

- The Contractor CSP can include a CAAS utilization strategy plan during D\&D, noting particularly where the strategy plan deviates from ANSI/ANS-8.3 and/or DOE guidance. This information shall also be included in the facility's safety basis documentation.

- The Contractor may develop realistic IEZ distances for each facility in lieu of one specific distance (e.g., 200 feet). This could help in the placement of portable devices. The methodology for the IEZ determination should be included in the DOE approved safety basis documentation. The use of portable devices should also be discussed in the safety basis documentation at the same level as the CAAS system that is being replaced.

\section{CAAS De-Activation or Removal Requirements}

Facilities that have had CAAS coverage during operations and often during surveillance and maintenance (S\&M) mode may not require CAAS coverage during S\&M and/or D\&D. It is important that the determination (e.g., non-credible NCSE) that the risk of criticality is sufficiently low to remove CAAS is made and the documentation supporting that conclusion is developed and approved by the Contractor NCS and the DOE. The DOE approval will be part of the DSA/TSR documentation approval process (e.g. the TSR LCO “applicability” can be defined so that a change is not required once the defined step-out criteria is met or Contractor can submit a DSA/TSR change to 
remove CAAS after the field conditions are met for removal.) It is also important that key elements of the NCS Program remain strong and intact during D\&D.

A recommended approach to obtaining approval of CAAS de-activation and/or removal includes:

- A DOE-approval of step-out criteria for CAAS in the DSA/TSR. The information provided in the safety basis document shall address the following:

o Establish how the determination will be made that CAAS is not required - e.g. NCS Program determines that there is no longer a credible criticality risk (could be with existence of some controls for just removal of CAAS)

0 Evaluate the remaining mitigating risk after CAAS is de-activated/ removed.

o Adequately identify the alternate detection/notification and hazard mitigation process being proposed. Provide justification of why the proposed control suite is acceptable for the specific facility level of criticality risk. This can be facility-specific based on the actual facility risk and activities.

o Address assurance that NCS resources/staffing is adequate and available to respond quickly and evaluate thoroughly any potential NCS non-compliances and resulting temporary placement of CAAS or use of personal alarming dosimetry.

- Continue NCS oversight and assessments

- Assure worker training remains adequate to recognize fissile material hold-up and NCS noncompliance condition response during $\mathrm{D} \& \mathrm{D}$

\section{CONCLUSION}

D\&D presents a number of challenges to the NCS Program. It is imperative that the DOE and the Contractors put standards, guidelines, and programs in place that provide flexibility in D\&D operations and other special situations while maintaining nuclear criticality safety.

The contractor needs to determine if the overall risk of installing/maintaining a formal ANSI/ANS 8.3 fully compliant CAAS is the best solution for a D\&D facility. An evaluation to determine if facility-specific adjustments are warranted is based on a comprehensive risk evaluation of all information in accordance with DOE Order 420.1B, ANSI/ANS series 8 standards, scope of activity, and the Contractor's NCS program. The Contractor needs to work closely with their DOE oversight to ensure that all agree on the path forward to prevent unacceptable delays, cost, and risk. The "adjustments" may be as simple as modification of remote monitoring expectations all the way to acceptance of a strategy that does not include a fixed system. The evaluation needs to be appropriately documented in the facility safety basis documentation and approved by DOE. 
APPENDIX C

TN-09 



\section{APPENDIX C \\ TN-09}

\section{RECENT CONTRACTING PRACTICES AT EM SITES HAVE LED TO SAFETY PROBLEMS}

The historic practice in DOE contracting was for large organizations with considerable infrastructure to manage much of our real estate and operations. These large-scope contracts were relatively simple for the government to develop and to oversee. Recent practice has been to break up these large-scope contracts into multiple small ones. This has resulted in issues that affect the safety of DOE operations. It is suggested that the Request for Proposals (RFPs) for these multiple limitedscope contracts include remedies to mitigate these issues.

In this regard, eight recommendations have been developed from the consensus fallout of the several ORNL-coordinated EM-21 workshops that engaged DOE staff who have responsibility for criticality safety oversight. Also participating and providing input were numerous representatives constituting a mix of the very freshman to the more senior nuclear criticality safety (NCS) programs throughout the DOE complex. Each of these eight recommendations is followed by the italicized text/basis that describes the DOE and contractor consensus description of current DOE contracting practice.

Requests for Proposals on multiple limited-scope contracts should address these six recommendations:

1. How the winning companies will manage the resultant distribution of specialized staff, such as criticality safety engineers.

The resultant NCS staff distribution is usually unbalanced in terms of staff expertise.

2. How the winning companies with multiple NCS groups will ensure compatible control measures for nuclear material that will move from one organization to another.

Movement of fissile material from one contractor to another becomes complicated since the control development practices inevitably diverge between shipper and receiver.

3. The proposal or the proposal presentation should clearly show that the bidder understands the infrastructure and level of effort needed to operate safety programs in a highly regulated environment.

The smaller contractors generally lack experience dealing with nuclear and criticality safety requirements. Hence, they are slow to understand the need for infrastructure for the two programs. Examples include not understanding the software requirements for NCS, the review and approval expectations for NCS evaluations, the implementation of a fully compliant DOE Order 420.1B program, how other activities can impact NCS and/or safety basis, and compliance with 10 CFR 830 Subpart B. Oftentimes, the contractors are unrealistic in the expectations and do not appropriately fund staffing and other activities (e.g., operator training, NCS engineer training, assessments, DSA/TSR development, USQD programs, analysis for the ever-changing D\&D facility, etc.).

4. The RFP should make clear which well-developed management control systems are required. With the smaller contractors, the resources that are needed for a good overall NCS program are harder to protect. NCS relies on many other safety management programs such as configuration 
control, quality assurance, NDA, document management, and operations. So when these areas are smaller or nonexistent, that can cause problems with the NCS program compliance as well.

5. If the RFP allows for significant replacement of experienced staff, then the proposal should explain how the effects of this transition in staff knowledge will be managed.

In the past, contract change involved largely the management chain; thus, the effect on safety performance was minimal. More recently, new contracts have come with essentially an entirely new staff. The learning curve is necessarily steep, and this is exacerbated by poor documentation of site conditions and inadequate processes to transmit "tribal knowledge."

The new contractors usually need to build infrastructure "from scratch," rather than accept existing management systems and make changes gradually as appropriate. Even if prior procedures exist at the time of transition, they normally cannot be performed as written with the new embryonic systems. It is unlikely that new safety management programs are ready to meet federal requirements, since the personnel and infrastructure are not established. A contractor cannot be expected to show up on-site with a full complement of documentation and productive personnel. Previously, these resources transitioned with the contract. Now a large portion of funding must go into creation of the documentation and infrastructure instead of directly into risk/hazard reduction.

DOE must develop a significantly enhanced oversight program for these new programs, in particular before operations, including D\&D, commences (for example, NCS software QA and ANSI/ANS requirements; ISMS phase I and II assessments; and with new infrastructure, the grading of activities in accordance with 425.1C).

6. The RFP should make clear the necessity of balancing cost, schedule, and safety. The high "award" for finishing contract objectives early can create an incentive for expeditious performance over good safety practice. This encourages the contractor to take unnecessary risks and creates problems for the safety personnel. Contractual emphasis on schedule and low contractual penalty for safety noncompliances result in job atmospheres in which personnel are "pressured" into taking shortcuts.

The final two recommendations address contract management and staffing needs, both DOE and contractor, for effective criticality safety program execution over the life of the contract.

7. If the contract is for a relatively short period, the department needs to have a plan to address the contractor's limited ability to train, qualify, and retain experienced staff.

NCS personnel generally decide to support long-term contractors unless short time contracts yield higher compensation. Cost and program stability are at issue. Under limited-scope contracts, training of personnel and establishment of good programs are just being completed at the time the contract ends.

A more general concern is that short contracts lack incentives for preventative maintenance, maintenance of qualifications, and engagement in future initiatives. Resulting structures are not maintained because surveillance and maintenance were deemed not required/not desirable based on the time the contractor would have the facilities. Personnel are not encouraged to participate in continued professional development, because the contractor would not be able to "benefit" from the activity.

8. DOE must develop the staff and structure to oversee limited-scope contracts.

At EM sites it is common for a contract to be awarded to a safety and management contractor for a specified period and a separate contract to be awarded for $D \& D$ of a portion of the facilities. Then another contract is awarded for D\&D of another portion of the facilities. The trade personnel can be working one day under one set of requirements and then the next day working 
under totally different criteria. For program management personnel, integration of the work activities is difficult. The evaluation of the impact of other contractor activities on your programs is difficult. The difficulty grows exponentially with the number of contractor activities requiring integration. DOE has experienced considerable difficulty with oversight of the multiple contractors and ensuring integration of activities. With limited DOE personnel, the concept of overseeing multiple contractors with differing safety and health programs (e.g., NCS, radiological, fire, IH, IS, waste management) is problematic. Additional DOE staff resources are required. 

APPENDIX D

TN-01 



\section{APPENDIX D}

TN-01

\section{Problem Area}

- Problem Area \#1

$>$ Inconsistencies and lack of clarity in DOE Orders, Standards, and Guides results in inefficiencies

- Purpose of effort underway

$>$ identify inconsistencies between "DOE Orders, Standards, and Guides",

$>$ identify instances where written DOE requirements/guidance is contrary to that desired, and

$>$ identify instances where a lack of clarity in written DOE requirements/guidance is causing inefficiencies

- Scope of documents involved

$>$ DOE Order 420.1B, Facility Safety

$>$ DOE Standard 3007, Guidelines for Preparing Criticality Safety Evaluations at Department Of Energy Nonreactor Nuclear Facilities

$>$ DOE Standard 1134, Review Guide for Criticality Safety Evaluations

> DOE Standard 1027, Hazard Categorization and Accident Analysis Techniques for Compliance with DOE Order 5480.23 , Nuclear Safety Analysis Reports

$>$ DOE Standard 3009, Preparation Guide for U. S. Department of Energy Nonreactor Nuclear Facility Documented Safety Analyses

> DOE Guide 421.1-1, Criticality Safety Good Practices Program Guide for DOE Nonreactor Nuclear Facilities

$>$ DOE Guide 421.1-2, Implementation Guide for Use in Developing Documented Safety Analysis to Meet Subpart $B$ of 10 CFR 830

$>$ DOE Guide 423.1-1, Implementation Guide for Use in Developing Technical Safety Requirements

$>$ DOE Guide 424.1-1A, Implementation Guide for Use in Addressing Unreviewed Safety Question Requirements 


\section{Actions Taken to Date}

\section{- Action Plan developed}

- Defined objective and scope of the effort

- Defined sequence of steps

- Defined roles and responsibilities

- Process Lead

- Working Group

- Participating Entities

- Includes an itemized list of "areas of concern"

- Living document

\section{Actions Taken to Date}

- Steps completed

- Action Plan developed and agreed to by Working Group

- "Area of Concern" template developed and agreed to Working Group

- Initial set of examples drafted by Working Group members

- DOE-EM Participating Entities asked to identification of areas of concern

- Total of 19 Area of Concerns submitted - some were repeats, some contained more than one issue

- The Process Lead reviewed all Areas of Concerns submitted and distilled down to 21 fundamental issues 


\section{Fundamental Issues}

\section{- Recurring Issues}

- Inappropriate requirements: inclusion of DSA requirements/expectations in NCSE Standard

- Insufficient guidance: elevating NCS controls into DSA \& TSR

- Insufficient guidance: definition of "Nature of Process"

- Inconsistent requirements: DOE-STD-3007 \& ANS-8.1 definitions of Double Contingency Principle

- Inappropriate requirement: potential for inadvertent criticality requires initial HC-2 determination

- Insufficient guidance: CSP Description Document content expectations

\section{Fundamental Issues}

\section{- Other Issues}

- Inconsistent requirements: related to configuration management of NCS controls

- Inconsistent requirements: allowed use of "sensitivity and uncertainty" tools were no experimental data is available to validate a computational method

- Insufficient guidance: DOE approval process for DCP deviations

- Insufficient guidance: back fitting DCP deviation approval requirement of 0 420.1B

- Insufficient guidance: change control process to invoke DOE approval for proposed DCP deviations (analogous to risk acceptance and the USQ process) 


\section{Fundamental Issues}

\section{- Other Issues}

- Inconsistent requirements: treatment of beyond design basis, credible events

- Inappropriate requirement: elevation of DCP recommendation to a requirement requiring DOE approval for deviations

- Inappropriate requirement: requiring documented justification for deviations from ANS 8 recommendations

- Inappropriate expectations: inclusion of CSP description document expectations in the NCSE standard

- Insufficient guidance: related to "special case" NCSE expectations

\section{Fundamental Issues}

- Other Issues

- Insufficient guidance: clarity of expectations related to mitigated incredible scenarios

- Insufficient guidance: definition of unlikely

- Inconsistent requirements: source of criticality safety requirements for transportation activities

- Inconsistent requirements: prohibition against establishment of minimum failure criteria for determining credibility of an inadvertent criticality

- Inconsistent requirements: treatment of low probability, incredible events 


\section{Next Step}

- Step 5 of the Action Plan - Working Group to:

- Evaluate the legitimacy of each "issue", document the basis for dismissing any as not legitimate

- Prioritize remaining issues

- Discuss possible resolutions

- Define, conceptually, resolution and assign follow-up actions to resolve

- Close on actions and document proposed solution

- Where appropriate, develop proposed "page changes" to affected DOE documents

- Feedback \& further input welcome during process

- Expected completion date 12/19/2008 (?)

EM Environmental Management

\section{Follow-on Actions}

- Delivery product to EM

- It is expected that any proposed changes to DOE documents resulting from this effort will be subjected to the normal document change processes (i.e. REVCOM) 

APPENDIX E

TN-04 



\title{
Information Preservation and Dissemination
} - Technical Program Element

\author{
from \\ The MISSION AND VISION of the \\ US DOE Nuclear Criticality Safety Program
}

\section{Lori Scott}

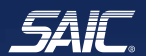

Email: lorisc0tt@aol.com

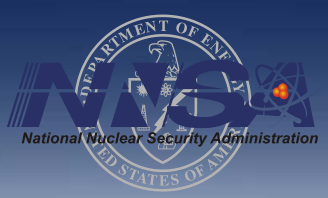

EM-60 Workshop - Anaheim, California - 13 June 2008

\section{Information Preservation and Dissemination}

One of six technical program elements of the NCSP.

The six technical program elements are:

- Analytical Methods

- Information Preservation and Dissemination

- Integral Experiments

- International Criticality Safety Benchmark Evaluation Project

- Nuclear Data

- Training and Education

Newly published Mission and Vision is available at http://ncsp.IInl.gov. 


\section{MISSION}

EM-60 Workshop - Anaheim, California - 13 June 2008

The Information Preservation and Dissemination (IP\&D) program element preserves primary documentation supporting criticality safety and makes this information available for the benefit of the technical community. The NCSP internet website (http://ncsp.IInl.gov) is the central focal point for access to criticality safety information collected under the NCSP, and the gateway to a comprehensive set of hyperlinks to other sites containing criticality safety information resources.

\section{IP\&D Vision}

The IP\&D element will identify, preserve, and disseminate selected technical, programmatic, and operational information that enables those responsible for criticality safety to sustain, enhance, and continually improve performance in support of safe efficient fissionable material operations.

\section{IP\&D Strategy}

The following strategy has been developed to direct the IP\&D element towards achieving its vision. The IP\&D element will:

- Establish a structured approach to using expert groups and individuals that will assist in identifying and selecting existing sources of organized information and other types of technical, programmatic, and operational information for preservation.

- Establish an easily accessible repository(ies) that can be sustained to provide for preservation and digital dissemination of the selected information.

- Conduct succession planning to provide continuity of expertise and prepare the next generation of leaders.

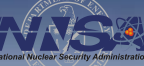

EM-60 Workshop - Anaheim, California - 13 June 2008

\begin{tabular}{|c|c|c|c|c|c|}
\hline & & Repos & $\begin{array}{l}\text { NCSP IP\&D } \\
\text { ory for Criti }\end{array}$ & $\begin{array}{l}\text { OT PROJECT } \\
\text { ity Safety Evaluations }\end{array}$ & \\
\hline SITE & POC & TELEPHONE & FACSIMILE & EMAIL & COMMENTS \\
\hline EM SITES & & & & & \\
\hline Hanford & Ray Puigh & $509-376-3766$ & $509-376-5396$ & Raymond_Puigh@rl.gov & \\
\hline & David Erickson & $509-376-4146$ & $509-376-5396$ & David G Erickson@rl.gov & \\
\hline INL (BEA) & $\begin{array}{l}\text { Todd Taylor } \\
\text { (Chair) }\end{array}$ & $208-526-9656$ & $208-526-0518$ & j.taylor@inl.gov & \\
\hline & Chad Pope & 208-533-7745 & 208-533-7239 & chad.pope@inl.gov & \\
\hline INL (CWI) & Mike Thieme & $208-526-0137$ & 208-526-9165 & Michael.Thieme@icp.doe.gov & \\
\hline INL (BWXT) & Rick Moore & 208-557-7147 & 208-557-7225 & MOORRL@amwtp.inl.gov & \\
\hline $\begin{array}{l}\text { ORNL } \\
\text { (Bechtel Jacobs) }\end{array}$ & Jeff Castor & $865-576-5106$ & & castorjs@bechteljacobs.org & \\
\hline ORNL (UT- & Davis Reed & $865-576-6359$ & $865-576-6011$ & reedda@ornl.gov & \\
\hline BAI IELLE) & Mike Westfall & $865-574-5269$ & $865-574-3527$ & WestfallRM@ORNL.gov & \\
\hline SRS (WSMSMGI) & Mike Low & 803-502-9751 & & mike.low@wsms.com & \\
\hline & Fitz Trumble & 803-502-9615 & 803-502-9773 & Fitz.Trumble@wsms.com & \\
\hline GDP (Portsmouth & ind Paducah) & & & & \\
\hline BNFL & Gary Smolen & 865-241-4579 & & gsmolen@bnfl-ettp.com & \\
\hline Paducah & Kristan Wessels & $270-441-5177$ & & KristenWessels@prs-llc.net & \\
\hline USEC & Jim Harris & $270-441-6759$ & & harrisjd@pgdp.usec.com & \\
\hline Non EM SITES & & & & & \\
\hline LANL & Shean Monahan & $505-665-7567$ & $505-665-4970$ & spm@lanl.gov & \\
\hline & Doug Bowen & $505-667-5939$ & $505-665-4970$ & dgbowen@lanl.gov & \\
\hline LLNL & David Heinrichs & 925-424-5679 & 925-423-2854 & heinrichs1@llnl.gov & \\
\hline & John Pearson & $925-423-2468$ & $925-423-2854$ & pearson3@IInl.gov & \\
\hline Pantex & Linda Vickers & $806-477-6617$ & $806-477-6845$ & Ivickers@pantex.com & \\
\hline & Lisa Vickers & $806-477-7302$ & $806-477-6845$ & Irvicker@pantex.com & \\
\hline Y-12 (BWXT) & Chris Robinson & $865-574-8509$ & $865-241-2772$ & robinsonrc@y12.doe.gov & \\
\hline SNL & Ron Knief & $505-284-6593$ & $505-284-3537$ & raknief@sandia.gov & \\
\hline
\end{tabular}


APPENDIX F

TN-07 



\section{APPENDIX F}

TN-07

Table F.1. Summary of Needs for Differential Data Development

\begin{tabular}{|c|c|c|c|c|c|}
\hline $\begin{array}{c}\text { Technology } \\
\text { Need }\end{array}$ & $\begin{array}{l}\text { DOE Site and Task } \\
\text { (Organization) }\end{array}$ & Technical Area & $\begin{array}{l}\text { Material(s) and } \\
\text { Isotopes }\end{array}$ & Priority & $\begin{array}{l}\text { Force } \\
\text { Rank }\end{array}$ \\
\hline 1 & $\begin{array}{c}\text { SRS-12 } \\
\text { (Parsons) }\end{array}$ & $\begin{array}{l}\text { DD: Measure thermal } \\
\text { cross sections for Ti, } \\
\text { evaluate uncertainties }\end{array}$ & $\begin{array}{l}\text { Actinides plus } \\
\text { monosodium titanate } \\
\text { (MST) salt waste }\end{array}$ & High & 1 \\
\hline 2 & $\begin{array}{c}\text { SRS-9 } \\
\text { (SRNS) }\end{array}$ & $\begin{array}{l}\text { S/U, DD: Pb reflection } \\
\text { on shipping container }\end{array}$ & $\begin{array}{l}\text { Pb uncertainty data } \\
\text { testing }\end{array}$ & Medium & 4 \\
\hline 3 & $\begin{array}{l}\text { SRS-10 } \\
\text { (Parsons) }\end{array}$ & $\begin{array}{l}\text { DD: Measure thermal } \\
\text { cross sections for } \mathrm{Na} \text {, } \\
\text { evaluate uncertainties }\end{array}$ & $\begin{array}{l}\text { Actinides plus MST } \\
\text { salt waste }\end{array}$ & Medium & 3 \\
\hline 4 & $\begin{array}{c}\text { SRS-7 } \\
\text { (WSRC) }\end{array}$ & $\begin{array}{l}\text { DD: Measure Gd cross } \\
\text { sections in fast neutron } \\
\text { spectra }\end{array}$ & $\begin{array}{l}\text { Non-MOX Pu } \\
\text { disposition with } \\
\text { absorbers }\end{array}$ & Low & 7 \\
\hline 5 & $\begin{array}{c}\text { SRS-5 } \\
\text { (WSRC) }\end{array}$ & $\begin{array}{l}\text { DD: Examine } \\
\text { uncertainty data for } \mathrm{Pu} \\
\text { in glass with absorbers } \\
(\mathrm{Fe}, \mathrm{Gd}, \mathrm{Na}, \mathrm{Mn}, \mathrm{B}, \mathrm{Si})\end{array}$ & $\begin{array}{l}\text { Non-MOX Pu } \\
\text { disposition with } \\
\text { absorbers }\end{array}$ & Low & 6 \\
\hline 6 & $\begin{array}{c}\text { SRS1 } \\
\text { (SRNS) }\end{array}$ & $\begin{array}{l}\text { DD: Examine } \\
\text { uncertainties and/or } \\
\text { measure thermal and } \\
\text { epithermal cross } \\
\text { sections }\end{array}$ & $\begin{array}{l}\text { Mo-HEU (20 and } \\
93 \% \text { U-235), } \\
\text { research reactor fuel } \\
\text { in reprocessing }\end{array}$ & Low & 5 \\
\hline 7 & $\begin{array}{l}\text { ORO-4 } \\
\text { (Isotek) }\end{array}$ & $\begin{array}{l}\text { BD, DD: Upgrade U- } \\
\text { 233 solution } \\
\text { benchmarks-SCALE } \\
\text { and MCNP validations }\end{array}$ & $\begin{array}{l}\text { U-233 in } 11 \text { critical } \\
\text { solutions, new } \\
\text { SCALE } \\
\text { technologies, MCNP } \\
\text { models and cross } \\
\text { sections }\end{array}$ & High & 2 \\
\hline
\end{tabular}

$\mathrm{BD}=$ benchmark data

$\mathrm{DD}=$ differential data

$\mathrm{S} / \mathrm{U}=$ sensitivity/uncertainty

MOX = mixed oxide

WSRC $=$ Westinghouse Savannah River Company

SRNS = Savannah River Nuclear Solutions, LLC 
Table F.2. Summary of Needs for Integral Data Development

\begin{tabular}{|c|c|c|c|c|c|}
\hline $\begin{array}{l}\text { Technology } \\
\text { Need }\end{array}$ & $\begin{array}{l}\text { DOE Site and Task } \\
\text { (Organization) }\end{array}$ & Technical Area & $\begin{array}{l}\text { Material(s) and } \\
\text { Isotopes }\end{array}$ & Priority & $\begin{array}{l}\text { Force } \\
\text { Rank }\end{array}$ \\
\hline 8 & $\begin{array}{l}\text { ORO-3 } \\
\text { (Isotek) }\end{array}$ & $\begin{array}{l}\text { ID, BD: Critical and } \\
\text { subcritical experiments } \\
\text { performed and } \\
\text { benchmarked }\end{array}$ & $\begin{array}{l}\text { U-233 in } \\
\text { intermediate neutron } \\
\text { energy spectra }\end{array}$ & High & 2 \\
\hline 9 & $\begin{array}{c}\text { SRS-13 } \\
\text { (Parsons) }\end{array}$ & $\begin{array}{l}\text { ID, BD: Subcritical, } \\
\text { critical experiments for } \\
\text { Ti in thermal neutron } \\
\text { spectra }\end{array}$ & $\begin{array}{l}\text { Actinides plus } \\
\text { monosodium } \\
\text { titanate (MST) salt } \\
\text { waste }\end{array}$ & High & 1 \\
\hline 10 & $\begin{array}{c}\text { SRS-11 } \\
\text { (Parsons) }\end{array}$ & $\begin{array}{l}\text { ID: Subcritical, critical } \\
\text { experiments for Na in } \\
\text { thermal neutron spectra }\end{array}$ & $\begin{array}{l}\text { Well-defined } \\
\text { amount of Na in } \\
\text { thermal systems }\end{array}$ & Medium & 3 \\
\hline 11 & $\begin{array}{c}\text { SRS-4 } \\
\text { (WSRC) }\end{array}$ & $\begin{array}{l}\text { ID: Experiments for } \\
\mathrm{Pu} \text { in glass DWPF } \\
\text { spectra with absorbers } \\
(\mathrm{Fe}, \mathrm{Gd}, \mathrm{Na}, \mathrm{Mn}, \mathrm{B}, \mathrm{Si})\end{array}$ & $\begin{array}{l}\text { Non-MOX Pu } \\
\text { disposition with } \\
\text { absorbers }\end{array}$ & Low & 6 \\
\hline 12 & $\begin{array}{l}\text { SRS-14 } \\
\text { (SRNS) }\end{array}$ & $\begin{array}{l}\text { ID, BD: Subcritical, } \\
\text { critical experiments for } \\
\text { Mo in thermal neutron } \\
\text { spectra, } \\
\text { (uranyl nitrate solution) }\end{array}$ & $\begin{array}{l}\text { Mo-HEU ( } 20 \text { and } \\
93 \% \text { U-235), } \\
\text { research reactor fuel } \\
\text { in reprocessing }\end{array}$ & Low & 5 \\
\hline 13 & $\begin{array}{c}\text { PPPO-1 } \\
\text { (EM/Paducah) }\end{array}$ & $\begin{array}{l}\text { CD, ID: Modeling } \\
\text { assistance in } \\
\text { characterizing fissile } \\
\text { materials in landfills }\end{array}$ & $\begin{array}{l}\text { U mass limits as a } \\
\text { function of } \\
\text { enrichment, } \\
\text { compounds and } \\
\text { admixed materials }\end{array}$ & Low & 4 \\
\hline
\end{tabular}

$\mathrm{BD}=$ benchmark data

$\mathrm{CD}=$ chemical data

ID = integral data

MOX = mixed oxide

WSRC = Westinghouse Savannah River Company

SRNS = Savannah River Nuclear Solutions, LLC 
Table F.3. Summary of Needs for Chemical Data Development

\begin{tabular}{|c|c|c|c|c|c|}
\hline $\begin{array}{l}\text { Technology } \\
\text { Need }\end{array}$ & $\begin{array}{l}\text { DOE Site and Task } \\
\text { (Organization) }\end{array}$ & Technical Area & $\begin{array}{l}\text { Material(s) and } \\
\text { Isotopes }\end{array}$ & Priority & $\begin{array}{l}\text { Force } \\
\text { Rank }\end{array}$ \\
\hline 14 & $\begin{array}{c}\text { ORO-5 } \\
\text { (ORNL, proposed } \\
\text { work) }\end{array}$ & $\begin{array}{l}\text { CD: Chemical data to } \\
\text { better characterize } \\
\text { actinides and } \\
\text { absorbers in solution }\end{array}$ & $\begin{array}{l}\text { U, Pu, absorbers in } \\
\text { solutions, } \\
\text { temperature and } \\
\text { molarity }\end{array}$ & High & 1 \\
\hline 15 & $\begin{array}{c}\text { PPPO-1 } \\
\text { (EM/Paducah) }\end{array}$ & $\begin{array}{l}\text { CD, ID: Modeling } \\
\text { assistance in } \\
\text { characterizing fissile } \\
\text { materials in landfills }\end{array}$ & $\begin{array}{l}\text { U mass limits as a } \\
\text { function of } \\
\text { enrichment, } \\
\text { compounds and } \\
\text { admixed materials }\end{array}$ & High & 2 \\
\hline 16 & $\begin{array}{c}\text { SRS-8 } \\
\text { (WSRC) }\end{array}$ & $\begin{array}{l}\text { CD: Measure } \\
\text { adsorption of actinides } \\
\text { onto monosodium } \\
\text { (MST) and behavior of } \\
\text { MST }\end{array}$ & $\begin{array}{l}\text { Actinides plus MST } \\
\text { salt waste }\end{array}$ & $\begin{array}{l}\text { Medium } \\
\text { (SRNL } \\
\text { will } \\
\text { address) }\end{array}$ & 3 \\
\hline 17 & $\begin{array}{c}\text { SRS-3 } \\
\text { (WSRC) }\end{array}$ & $\begin{array}{l}\text { CD, Behavior of Fe, } \\
\text { Gd, Pu in DWPF } \\
\text { melter }\end{array}$ & $\begin{array}{l}\text { Non-MOX Pu } \\
\text { disposition }\end{array}$ & $\begin{array}{l}\text { Medium } \\
\text { (SRNL } \\
\text { will } \\
\text { address) }\end{array}$ & 3 \\
\hline 18 & $\begin{array}{c}\text { SRS-2 } \\
\text { (WSRC) }\end{array}$ & $\begin{array}{l}\text { CD: Solubility of Gd } \\
\text { in nitric/formic acid }\end{array}$ & $\begin{array}{l}\text { Non-MOX Pu } \\
\text { disposition }\end{array}$ & $\begin{array}{l}\text { Medium } \\
\text { (SRNL } \\
\text { will } \\
\text { address) }\end{array}$ & 3 \\
\hline
\end{tabular}

$\mathrm{BD}=$ benchmark data

$\mathrm{CD}=$ chemical data

ID $=$ integral data

MOX = mixed oxide

WSRC = Westinghouse Savannah River Company

SRNS = Savannah River Nuclear Solutions, LLC 
Table F.4. Summary of Needs for Non-Destructive Assay (NDA) Technologies

\begin{tabular}{|c|c|c|c|c|c|}
\hline $\begin{array}{l}\text { Technology } \\
\text { Need }\end{array}$ & $\begin{array}{l}\text { DOE Site and Task } \\
\text { (Organization) }\end{array}$ & Technical Area & $\begin{array}{l}\text { Material(s) and } \\
\text { Isotopes }\end{array}$ & Priority & $\begin{array}{l}\text { Force } \\
\text { Rank }\end{array}$ \\
\hline 19 & $\begin{array}{c}\text { Hanford-2 } \\
\text { (TRU and CERCLA) }\end{array}$ & $\begin{array}{l}\text { NDA: Techniques } \\
\text { and integral data }\end{array}$ & $\begin{array}{l}\text { Actinides } \\
\text { (CERCLA) }\end{array}$ & High & 2 \\
\hline 20 & $\begin{array}{c}\text { West Valley-1 } \\
\text { (Decommissioning } \\
\text { and TRU Waste) }\end{array}$ & $\begin{array}{l}\text { NDA: In-situ } \\
\text { fissionable assay in } \\
\text { high-gamma field }\end{array}$ & $\begin{array}{l}\text { LEU, Pu }>15 \% \mathrm{Pu}- \\
240 \text { (spent fuel and } \\
\text { waste forms) }\end{array}$ & High & 4 \\
\hline 21 & $\begin{array}{c}\text { West Valley-2 } \\
\text { Decommissioning } \\
\text { and TRU Waste) }\end{array}$ & $\begin{array}{l}\text { NDA: Fissionable } \\
\text { assay in high-gamma } \\
\text { or TRU waste stream }\end{array}$ & $\begin{array}{l}\text { LEU, } \mathrm{Pu}>15 \% \mathrm{Pu}- \\
240 \text { (spent fuel and } \\
\text { waste forms) }\end{array}$ & High & 5 \\
\hline 22 & $\begin{array}{l}\text { ORO-2 } \\
\text { (Isotek) }\end{array}$ & $\begin{array}{l}\text { NDA: Technology } \\
\text { needed for both } \\
\text { containers and process } \\
\text { equipment holdup }\end{array}$ & $\begin{array}{l}\text { U-233, U-235, Gd, } \\
\text { Cd as oxides, } \\
\text { fluorides }\end{array}$ & Medium & 6 \\
\hline 23 & $\begin{array}{c}\text { PPPO-6 } \\
\text { (EM/PGDP and } \\
\text { PORTS) } \\
\end{array}$ & $\begin{array}{l}\text { NDA: Evaluation } \\
\text { criteria for assessment } \\
\text { of NDA programs }\end{array}$ & $\begin{array}{l}\text { U cascade operation, } \\
\text { D\&D applications }\end{array}$ & High & 3 \\
\hline 24 & $\begin{array}{c}\text { PPPO-7 } \\
\text { (EM/PGDP and } \\
\text { PORTS) }\end{array}$ & $\begin{array}{l}\text { NDA: Determination } \\
\text { of uncertainty values } \\
\text { for NDA } \\
\text { measurements }\end{array}$ & $\begin{array}{l}\text { U cascade operation, } \\
\text { D\&D applications }\end{array}$ & High & 1 \\
\hline 25 & $\begin{array}{c}\text { ORO-6 } \\
\text { (ORNL, proposed } \\
\text { Work) }\end{array}$ & $\begin{array}{l}\text { TM: Advanced fixed } \\
\text { neutron-gamma source } \\
\text { transport methods }\end{array}$ & $\begin{array}{l}\text { Actinides analyzed } \\
\text { for NDA and/or } \\
\text { subcritical assembly } \\
\text { purposes }\end{array}$ & Medium & 7 \\
\hline
\end{tabular}

TM $=$ transport methods

CERCLA = Comprehensive Environmental Response, Compensation, and Liability Act

$\mathrm{D} \& \mathrm{D}=$ decontamination and decommissioning

PGDP $=$ Paducah Gaseous Diffusion Plant

TRU $=$ transuranic 
Table F.5. Summary of Needs for Source Data, Criticality Accident Alarm Systems, and Transport Methods Technologies

\begin{tabular}{|c|c|c|c|c|c|}
\hline $\begin{array}{c}\text { Technology } \\
\text { Need }\end{array}$ & $\begin{array}{l}\text { DOE Site and Task } \\
\text { (Organization) }\end{array}$ & Technical Area & $\begin{array}{l}\text { Material(s) and } \\
\text { Isotopes }\end{array}$ & Priority & $\begin{array}{l}\text { Force } \\
\text { Rank }\end{array}$ \\
\hline 26 & $\begin{array}{l}\text { Hanford-1 } \\
\text { (TRU and } \\
\text { CERCLA) }\end{array}$ & $\begin{array}{l}\text { S/U, TM: Guidance- } \\
\text { Complex-wide } \\
\text { standard }\end{array}$ & Transuranics & High & 2 \\
\hline 27 & $\begin{array}{c}\text { SRS-6 } \\
\text { (WSRC) }\end{array}$ & $\begin{array}{l}\text { S/U, TM: Analyses of } \\
\text { Pu in glass for the } \\
\text { DWPF melter with } \\
\text { absorbers (Fe, Gd, Na, } \\
\text { Mn, B, Si) }\end{array}$ & $\begin{array}{l}\text { Non-MOX Pu } \\
\text { disposition with } \\
\text { absorbers }\end{array}$ & Low & 7 \\
\hline 28 & $\begin{array}{l}\text { ORO-1 } \\
\text { (Isotek) }\end{array}$ & $\begin{array}{l}\text { TM plus I\&C: } \\
\text { Criticality detection } \\
\text { system technologies } \\
\text { for heavily shielded } \\
\text { operations }\end{array}$ & $\begin{array}{l}\text { U-233, U-235, Gd, } \\
\text { Cd as oxides, } \\
\text { fluorides, in solution }\end{array}$ & High & 1 \\
\hline 29 & $\begin{array}{c}\text { PPPO-2 } \\
\text { (EM/PGDP and } \\
\text { PORTS) }\end{array}$ & $\begin{array}{l}\text { TM, I\&C: Develop } \\
\text { alternative CAAS } \\
\text { requirements for } \\
\text { cascade D\&D }\end{array}$ & $\begin{array}{l}\text { U in variable mass } \\
\text { amounts distributed } \\
\text { on equipment }\end{array}$ & Medium & 3 \\
\hline 30 & $\begin{array}{c}\text { PPPO-3 } \\
\text { (EM/PGDP and } \\
\text { PORTS } \\
\end{array}$ & $\begin{array}{l}\text { SD, TM: Modeling } \\
\text { assistance, MCNP } \\
\text { template }\end{array}$ & $\begin{array}{l}\text { Neutron sources } \\
\text { from U holdup }\end{array}$ & Medium & 6 \\
\hline 31 & $\begin{array}{c}\text { PPPO-4 } \\
\text { (EM/PGDP and } \\
\text { PORTS) }\end{array}$ & $\begin{array}{l}\text { SD, TM: Modeling } \\
\text { assistance in } \\
\text { characterizing neutron } \\
\text { background }\end{array}$ & $\begin{array}{l}\text { Neutron sources } \\
\text { from contaminants, } \\
\text { soil and atmospheric } \\
\text { components }\end{array}$ & Medium & 5 \\
\hline 32 & $\begin{array}{c}\text { PPPO-5 } \\
\text { (EM/PGDP and } \\
\text { PORTS) }\end{array}$ & $\begin{array}{l}\text { SD: Modeling } \\
\text { assistance for specific } \\
\text { activity of U-234 }\end{array}$ & $\begin{array}{l}\text { U-234 concentration } \\
\text { as a function of } \\
\text { cascade operation, } \\
\text { decay data for } \\
\text { neutron source term }\end{array}$ & Medium & 4 \\
\hline
\end{tabular}

$\mathrm{SD}=$ source data

I\&C = instruments and control

CAAS = criticality accident alarm system

$\mathrm{TM}=$ transport methods

S/U - sensitivity/uncertainty

PGDP $=$ Paducah Gaseous Diffusion Plant

WSRC $=$ Westinghouse Savannah River Company

$\mathrm{D} \& \mathrm{D}=$ decontamination and decommissioning 

APPENDIX G

TN-10 



\section{APPENDIX G \\ TN-10}

\section{HIRING, QUALIFICATION, AND RETENTION OF NCS ENGINEERS AT DOE FACILITIES}

\section{INTRODUCTION}

During the EM Conference on Nuclear Criticality Safety (NCS) in February 2008, the contractor operations and NCS subject matter experts expressed concerns because the retiring workforce and nuclear industry growth were creating deficiencies in qualified staffing.

This white paper defines the problems associated with hiring and retaining NCS engineers (including NCS engineer qualification) within the DOE complex and makes suggestions that could alleviate future concerns.

\section{BACKGROUND}

In order to better define the problem, a questionnaire was developed and distributed to DOE-EM NCS subject matter experts and DOE end users. The questionnaire asked questions relating to the number of open NCS engineer positions, NCS engineer qualification time, number of NCS engineer retirements, and issues encountered in hiring and retaining NCS engineers. Nine

companies/facilities/sites responded.

\section{HIRING}

DOE contractors have divergent concerns in hiring NCS engineers. A majority of the questionnaire respondents discussed an inability to attract trained and experienced NCS engineers. Other respondents, looking to hire recent graduates, stated that the competition with commercial nuclear facilities and the private sector inhibited the ability to attract engineers.

A combination of three issues has increased competition for new nuclear engineers. First, there is a significant increase in interest in nuclear power. This interest is being translated into the need for new engineers to build, fuel, and regulate the new reactors that are being proposed. Second, the nuclear industry workforce is aging, with $35-40 \%$ of the workforce eligible for retirement in the next 5 years. Third, the number of students enrolled in nuclear engineering programs has been declining in the recent past. (This trend is reversing but will take time to recover.) This combination of issues has created a near "perfect storm" for hiring new nuclear engineers. In addition to these issues, NCS engineers require significant additional training before they are productive NCS engineers.

The current magnitude of the nuclear engineering talent is still being determined. However, estimates 3 years ago indicated that for each new graduate there would be two new jobs available. The renewed interest in nuclear power has further exacerbated this problem.

The "perfect storm" has increased the competition for new talent, which is resulting in rapidly escalating salaries and benefits for new engineers. This will translate into salary pressures in the 
existing engineering pool. The added salary pressure is impacting the ability to attract or retain existing engineers, including NCS engineers.

\section{QUALIFICATION}

DOE O 5480.20A, DOE-STD-1135, and ANSI/ANS-8.26 require extensive on-the-job training and a rigorous qualification process. Because of these requirements, the time needed to qualify a new NCS engineer is 18-36 months.

While there is no dissention to the requirements set forth by both DOE and ANSI/ANS, other variables have the ability to increase the time required to qualify a new NCS engineer. The hindrances that increase qualification time include the availability of training courses (and obtaining the correct clearance levels), acquiring time in the facility, and convincing projects to accept the cost and time additions involved in allowing inexperienced personnel to perform analyses. In addition, on shorter contracts, DOE contractors do not have a time frame that allows for training new NCS engineers. This is especially true for small business contractors that do not have the infrastructure to support a qualification process.

\section{RETENTION}

The inability to hire recent graduates, the length of time and high cost to qualify a new NCS engineer, and the approaching retirement of a large percentage of NCS Engineers is increasing the demand for qualified NCS engineers. Based on DOE contractor response, the biggest hindrance in retaining qualified NCS engineers is higher compensation elsewhere. DOE contractors are losing qualified NCS engineers to other DOE contractors and to commercial entities looking to hire already qualified NCS engineers.

The following options could be considered separately or together to increase hiring of new NCS engineers and retention of existing NCS engineers:

- A DOE-approved deferred bonus for existing NCS engineers to stay in the current positions.

- A DOE-approved salary bonus for practicing NCS engineers. This bonus would be to discourage NCS engineers from going back to other nuclear-related jobs.

- A DOE-approved salary bonus for new NCS engineers entering the workforce.

- An accelerated review cycle of salaries for both NCS engineers and engineers with nuclearrelated skills that would allow DOE to modify any bonuses as required. 
